\title{
The Democratic Cost of Consecutive Re-election and Presidential Term-Limit Evasion in Latin America
}

\author{
Karel Kouba* (D) and Jan Pumr (D) \\ Department of Politics, Philosophical Faculty, University of Hradec Králové, Hradec Králové, \\ Czech Republic \\ *Corresponding author. Email: karel.kouba@uhk.cz
}

(Received 6 December 2020; revised 24 August 2021; accepted 27 August 2021;

first published online 3 December 2021)

\begin{abstract}
Despite theoretical arguments suggesting the strong effects of presidential term limits and re-election on democracy, there is surprisingly little empirical evidence to evaluate them. We test both the effect on democracy of the existence of a consecutive re-election rule and of reforms introducing it for incumbent presidents. Using evidence from Latin American countries between 1945 and 2018, we test their relationship to both vertical and horizontal accountability. A synthetic control method is employed to account for the effect of termlimit reforms, and time-series cross-section models for modelling the association with the re-election rule. Both vertical and horizontal accountability as well as the quality of democracy are eroded by term-limit evasion reforms in most countries and strengthened in none between 1990 and 2018. Allowing presidents to run for re-election - relative to term-limited ones - is consistently associated with weak democratic outcomes.
\end{abstract}

Keywords: term limits; Latin America; re-election; democracy; synthetic control method

As early as 650 to $600 \mathrm{BCE}$, citizens of the Greek polis of Dreros passed a law prohibiting the repetition in office of their leaders before a 10-year interval, and punishing such overstayers by depriving them of their civic capacities (Raaflaub and Wallace 2007: 23). The realization that uninterrupted personal rule negatively affects the life of the polis - and devising legal barriers to prevent it - have been linked to the constitution of democracy from its very beginning. So also have attempts to scrap these temporal constraints by political leaders. More recently, a surge of such attempts has spread around the world, but with a particular intensity in Latin America. What Alberto Fujimori of Peru or Hugo Chávez of Venezuela inaugurated in the 1990s, the likes of Daniel Ortega of Nicaragua or Juan Orlando Hernández of Honduras intensified in the 2010s. Across Latin America

(C) The Author(s), 2021. Published by Cambridge University Press on behalf of Government and Opposition Limited. This is an Open Access article, distributed under the terms of the Creative Commons Attribution licence (https://creativecommons.org/licenses/by/4.0/), which permits unrestricted re-use, distribution, and reproduction in any medium, provided the original work is properly cited. 
especially, this wave of term-limit evasion reverses the earlier codification of term limits in the third wave of democratization, which was based on the historical experience of authoritarian personalistic rules.

Does the scrapping of term limits by presidents to allow their immediate re-election cause the quality of democracy to decline? Does having a president who is eligible for immediate re-election cause the quality of democracy to deteriorate? This analysis attempts to answer both questions in a comparative perspective of Latin American countries between 1945 and 2018. Surprisingly, although there are powerful theoretical arguments on both sides concerning the virtues and vicissitudes of presidential re-election for democratic prospects (for reviews see Baturo and Elgie 2019; Carey 2003; Ginsburg et al. 2011), so far, there has been no systematic assessment of these expectations. This contrasts with the profusion of singlecase arguments which often link term-limit evasion to non-democratic outcomes. Most recently, the coup removing Evo Morales from the Bolivian presidency in 2019 has been seen as a reaction to his attempt at term-limit evasion rather than to his instituting of radical policies. By ignoring the results of the 2016 referendum, which voted against re-election, Morales focused most of his political agenda on staying in power, thus inviting polarization and the emergence of radical opposition figures which set the stage for his removal (Stefanoni 2020). Furthermore, the absence of research on the democratic effects of re-election rules is all the more surprising given that comparative research has paid much attention to their origins. Although we know a lot about the reasons why presidents pursue permissive reforms, why some succeed and continue in office, and under what conditions (Arana Araya 2021; Baturo 2010; Cassani 2020; Kouba 2016; McKie 2019; Sánchez 2013), the effects of such reforms are unknown.

Our goal in this article is twofold. We study both the effect on the quality of democracy of having a president who is not bound by term limits and of the introduction of a reform that allows him or her to stand for immediate re-election. Both approaches are conceptually related but are ultimately different questions with their relative (dis)advantages. The first approach allows one to estimate the average effect of a permissive re-election rule (relative to a restrictive one). Its advantage is that it can easily identify the periods of government under either particular rule and connect them directly to the (non-)democratic outcome. But such an approach raises some methodological challenges. First, term limits are endogenously chosen, which weakens the case for a causal inference (Baturo and Elgie 2019). Second, the first approach assumes a constant effect of re-election rules in all countries and all temporal periods. But this is a doubtful assumption because the effects of re-election may cause a deep crisis of democracy in the immediate aftermath of a successful term-limit contravention attempt, or these may kick in only later in a more gradual manner. The introduction of immediate re-election might outweigh the democratic institutions in the immediate aftermath of the reform but benefit overall democracy in the long run. Similarly, a country with a long history of permissive re-election rule may have institutionalized democratic competition over time around this formal rule without its core democratic institutions being challenged. But in a country where permissive re-election rules were initiated by a contentious (or even legally dubious) constitutional reform, the very act of removing term limits is conducive to democratic erosion and political instability. Considering such contextual 
influences, we propose a methodological strategy - the synthetic control method to accommodate these inferential challenges.

Theoretically, we approach the problem by disaggregating the effect on democracy into two dimensions: vertical and horizontal accountability, both of which should (normatively) ideally be maximized in a representative democracy (O'Donnell 1994). Vertical accountability allows citizens to voice their social demands to public officials and to hold those officials accountable should they betray their trust, and as such is supplied by reasonably free and fair elections in an institutional framework that respects civil and political rights (freedom of speech, press or association etc.). On the other hand, horizontal accountability implies the existence of checks and balances on the exercise of power through state agencies that are legally empowered to oversee and sanction possibly unlawful actions by other agents of the state (Lührmann, Marquardt and Mechkova 2020; O’Donnell 1998).

There are conflicting theoretical arguments among which we attempt to adjudicate. While some authors conclude that the possibility of re-electing presidents reinvigorates democracy by maximizing vertical (electoral) accountability, others suggest that term limits contrarily damage the electoral connection between voters and elected officials by hurting electoral competition. Moreover, some authors view consecutive re-election as conducive to the rise of an imperial presidency that consolidates sweeping powers while escaping and eliminating checks and balances (i.e. damaging horizontal accountability).

The article is structured as follows. The first section defines the concepts of term-limit evasion and of consecutive presidential re-election. The second section discusses the theoretical foundations of a relationship between presidential re-election and the democratic dimensions of horizontal and vertical accountability. After discussing the research design, data and variables, the third section presents the results of OLS models aimed at estimating the effects of re-election rules. The Online Appendix also presents results of propensity score-matching as a robustness test. The fourth section introduces the synthetic control method to understand how term-limit evasion shaped democratic outcomes in the third wave of democracy.

\section{Conceptualizing term-limit evasion and consecutive re-election}

To answer the two research questions, we differentiate between both related concepts whose democratic effects are examined. We define instances of term-limit evasion as those episodes in which presidents: (1) were elected; (2) faced a constitutional ban on immediate re-election at the entry to office; and (3) during whose mandate this ban was lifted to allow for their immediate re-election for a following term. This definition excludes cases of other types of permissive re-election rule change - for example, reforms that replaced absolute prohibition on re-election with non-consecutive re-election, as in Costa Rica 2003, when the constitutional chamber declared that an absolute ban on re-election was unconstitutional and then the chamber again permitted the possibility of non-consecutive re-election after eight years (Zovatto 2005: 152). It also excludes another principal means of presidential continuismo: term-limit avoidance, in which outgoing presidents leave office but install formal figureheads in their stead or in which they arbitrarily 
discard counting of mandates served under old constitutions (Baturo 2019). Our definition does not discriminate between two other types of continuismo: term extension (allowing re-election for only a single term, as in Peru in 1993 or Brazil in 1997) and term-limit avoidance (eliminating term limits altogether, as in Venezuela or Nicaragua; cf. Baturo 2019). Arguably, there is a difference between both categories, with the former one presenting a somewhat more benign type. But Latin American term-limit evaders are 'recidivists' who attempt further term-limit extension beyond the original single-term extension (Kouba 2016: 454). Some of these re-re-election attempts are not successful (e.g. Carlos Menem in Argentina, Álvaro Uribe in Colombia), while most succeed (e.g. Hugo Chávez in Venezuela, Daniel Ortega in Nicaragua).

The definition of periods under consecutive re-election is different. There, we include all cases (country-years) in which an elected president was eligible to run for a consecutive re-election (as opposed to those who are barred from doing so). This includes cases of term-limit evaders after their reform (but not prior to it) but also cases of presidents who inherited the possibility of consecutive re-election from their predecessors (Nicolás Maduro in Venezuela or Inácio 'Lula' da Silva during his first term in Brazil, but not during his second term). This distinction allows us to isolate the effect on democracy of the rule per se from the effect of instituting such a rule.

The definitions of both the periods following term-limit evasion and of consecutive re-election periods excludes periods in which non-elected heads of state governed. This is narrower than a broad definition that also includes overstayers who came to power through illegitimate means (for example, military coups) and overstayed the initial period mandated by the civilian constitution (see Ginsburg et al. 2011). Presidential term-limit evasion is a frequent occurrence. Globally, as many as $31 \%$ of presidents between 1975 and 2018 attempted to extend their mandate, of whom 33\% succeeded in lifting the ban indefinitely, $45 \%$ secured at least another term and only $22 \%$ failed in their attempt (McKie 2019). In Latin America, term-limit evasion was an infrequent occurrence until the 1990s, when a wave of dismantling of proscriptions on consecutive re-election was inaugurated (beginning with the attempt by Alberto Fujimori in Peru). Since 1945, there have been a total of 22 reforms allowing re-election, 15 of which occurred since 1990. In only seven countries have there been no changes allowing immediate re-election of incumbent presidents since 1945. The remaining 11 countries witnessed at least one such reform.

The Online Appendix (section 6) provides a descriptive overview of the evolution of re-election provisions in each Latin American country since 1945 and lists the sources for this coding.

\section{The democratic cost of term-limit evasion and consecutive re-election}

The theorized effects of reforming re-election rules on democracy can be usefully disaggregated along two dimensions of political accountability. The ideal of representative democracy is maximized in countries which complement the voterpolitician linkages of vertical accountability with a dense and functional web of horizontal accountability mechanisms and institutions (O'Donnell 1994). Where 
the former source of accountability dominates, the democratic practice is reduced to a mere 'delegative democracy' where the presidents - while legitimized by clean elections - sidestep, ignore or corrupt autonomous control institutions, including courts and congresses making those incapable of holding the presidents accountable. It is important to note that Guillermo O'Donnell's original definition of the ideal-typical delegative democracy implies the elimination of all brakes on presidential power save one - the temporal constraint of having to leave office at the end of the mandate: 'whoever wins election to the presidency is thereby entitled to govern as he or she sees fit, constrained only by the hard facts of existing power relations and by a constitutionally limited term of office' (O'Donnell 1994: 59). This presents a paradox from the perspective of term-limit evasion. On the one hand, term-limit evading presidents nominally buttress their vertical accountability as presenting themselves for another election allows voters to evaluate and electorally punish them. On the other hand, by promoting these reforms, horizontal accountability is further weakened (O'Donnell 1994: 67). We discuss below some implications of this paradox by focusing on the theorized effects of term-limit evasion on both horizontal and vertical accountability.

\section{Effects of term-limit evasion on vertical accountability}

There are two contradictory positions in the literature on whether the possibility of re-election undermines or enhances vertical accountability. On the positive side, presidential re-election may solve the fundamental problem of democracy by promoting accountability of elected officials to their voters. Some would go as far as to argue that the impossibility of re-election was more of an obstacle than a safeguard for democracy in Latin America in the 1990s because this restriction did not allow voters to retain competent presidents in office, and at the same time these presidents had no reason to follow voter preferences (Smith 2005: 160). Presidents who are ineligible to run for another term become partially unpredictable because voters can no longer punish them in the form of non-election in the next elections (Linz 1994: 12; Mainwaring and Shugart 1997: 461; Manin et al. 2001). The possibility of re-election is therefore an important mechanism through which presidents are held accountable and responsive to their constituents (Corrales and Penfold 2014; Linz 1998). This democratic choice is restricted when incumbent presidents are barred from running for office. After all, such a situation gives rise to candidacies of new and unknown politicians, and is unlikely to be rational, informed and independent (Linz 1998). Because term limits fundamentally interfere with the relationship between voters and presidents, they are considered a blunt instrument damaging to electoral accountability, so alternative institutional reforms that regulate the incumbency advantage should be sought instead (Cheibub and Medina 2019: 531).

A related line of reasoning suggests that re-electable presidents conform their political behaviour to better serve the needs of citizens. Ernesto Laclau argued forcefully for unlimited re-election in Latin America on the grounds that presidential systems necessitate strong political leaders to implement political and social change (Alconada 2012). Unlike in parliamentary systems, the processes of change crystalize around political leaders whose substitution by term limits creates political disequilibria. Governing is also made difficult for term-limited presidents due to 
the fixed terms of office under presidentialism, which together constitute a primary source of presidentialism's problematic rigidity (Linz 1994). The four to six years in office allow almost no major reforms to be undertaken. Under such conditions, smooth and efficient governing may be hindered by discontinuous and short-term policymaking by lame-duck presidents ineligible for re-election, blocking the access of able politicians and depriving the polity of the blessings of experience gained by their presidents, with potential for political conflicts ensuing as a result of succession crises, or the problematic cohabitation of the once powerful ex-presidents with the new political leadership (Del Campo 2009; Ginsburg et al. 2011; Linz 1994). Of particular concern in this respect is that re-election bans weaken the presidents as leaders of their parties. Legislators will be less inclined to support the president whose term will shortly expire. However, if they were to be re-elected, this would increase their chances of forming and maintaining legislative coalitions (Carey 2003).

Although there is sufficient theoretical reason for a positive link between re-election and vertical accountability, its contribution may be outweighed by important negative effects. Vertical accountability may be undermined under re-electable presidents because presidential re-election tilts the balance of electoral competition in favour of the incumbent. Whether due to a simple incumbency advantage' (Corrales and Penfold 2014) or due to a malevolent skewing of the playing field, incumbent presidents seeking re-election wield a substantial electoral advantage. Presidential contests where incumbents are allowed to run for re-election significantly reduce the share of votes received by political outsiders, possibly due to incumbency advantage (access to pork and state resources), which discourages the participation of independent candidates (Carreras 2012). Re-election also reduces the number of presidential candidates, thus limiting the alternative choice for voters (Crespo and Garrido 2008). According to this line of reasoning, incumbent presidents are already favoured by the powers of their office and therefore have a huge advantage over their opposition (Hellwig and Samuels 2008).

Conversely, term limits reinvigorate democratic competition because they promote alternation in power of both individuals and political parties (Corrales and Penfold 2014; Maltz 2007: 131; Martsteintredet 2019). This is important, especially in electoral-authoritarian regimes where the ineligibility of the president reduces the incumbency advantage of his party and may induce stronger cooperation among the opposition parties by providing a meaningful opportunity to win the election. Furthermore, a peaceful alternation in power appears to be possible only when consecutive re-election was banned in a comparison of Latin American countries from independence until 1985 (Marsteintredet 2019). The prohibition of presidential re-election was a necessary, though not sufficient, condition to establish democracy in Latin America (Marsteintredet 2019: 116).

\section{Effects of term-limit evasion on horizontal accountability}

If vertical accountability may be helped or hindered by re-election depending on theoretical perspective, horizontal accountability is the indisputable victim of permissive re-election rules, according to existing theories. In presidential systems, 
re-election strengthens the trend towards personalistic and hegemonic leadership and exposes the political system to the risk of a 'democratic dictatorship' or even an authoritarian regime (Zovatto 2014). The absence of term limits strengthens the president at the expense of other institutions, and weakens the system of checks and balances. It is mostly for these reasons that Latin American countries introduced restrictive reforms during the third wave of democratization and have tightened or even banned the possibility of re-election (McKie 2019). For some, the principle of no re-election is a necessary source of separation of powers in presidential systems. Re-election outweighs other powers in favour of the president, breaks the architecture of democracy and further weakens democratic institutions (Barbadillo 2011; Gaviria 2009: 76). Incumbent presidents are already advantaged by the powers of their office and therefore enjoy a power advantage over the opposition (Corrales 2009: 68; Guliyev 2009). Multiple re-election further implies a willingness to act above the law, which is detrimental to political life as democracy is the government of the law, not the government of the people (Rouquié 2011:317). The possibility of presidential re-election also limits the rotation of politicians in executive positions and increases the president's bargaining power towards legislators (Negretto 2011).

Furthermore, not only the rules themselves but the very attempt at scrapping term limits poses risks to the system of horizontal checks and balances. Oftentimes, incumbent presidents have succeeded in abolishing the article banning re-election by constitutionally dubious means, which would not otherwise have been passed by Congress. They were thus able to bypass the legislature and trample on the horizontal division of power (Negretto 2012; Sánchez 2013). However, not all such permissive reforms are similarly problematic, especially if they result from constructive negotiations across a broad political spectrum and arise as a common consensus. If the reform is carried out by the president without consulting the opposition forces, its negative effects prevail (Corrales and Penfold 2014). Furthermore, the institutional context in which such reforms materialize is important.

Finally, one should also consider the unintended consequences of term limits on democracy. The very event (or even attempt) of relaxing term limits by sitting presidents often invites strong opposition, which may at times result in an openly authoritarian reaction. The term-limit evasion by Paz Estenssoro of Bolivia itself triggered his early ouster from office by a military coup (Baturo 2019: 89). This event ushered the country into almost two decades of military rule. The 2009 military coup against President Manuel Zelaya in Honduras - due to his alleged attempt at term-limit evasion - did not result in military rule but highlighted the country's deficient democracy. In sum, the term-limit reforms may trigger an unpredictable chain of events - whether by design of the presidents themselves or by the opposition to those reforms - with deleterious consequences for the core democratic institutions.

\section{The effects of re-electability on democratic dimensions, 1945-2018}

For the analysis of the re-election rules' effects on democratic dimensions, we collected a data set containing yearly data from 18 Latin American countries between 


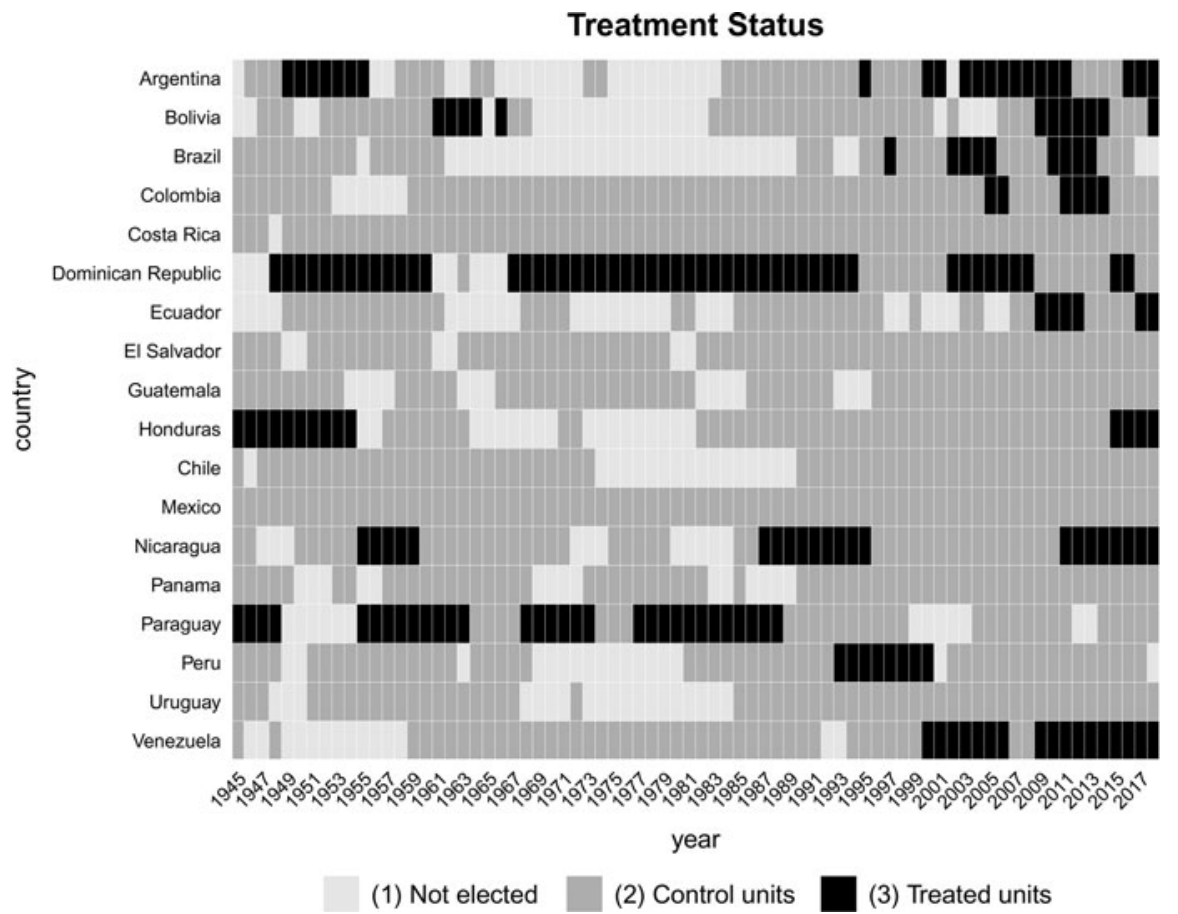

Figure 1. Treated, Control and Missing Units in the Analysis of Re-election Rules in Latin American Countries, 1945-2018

1945 and 2018 (1,332 cases). Of these country-years, 265 were set as missing because rulers other than elected presidents were heads of state. This category principally includes non-elected military governments, collegial government in Uruguay and interim presidents (presidents who exercised the mandate after the elected president deceased, resigned or was removed by a military coup etc.). The analysis is based on the remaining two categories. The treated units constitute 197 cases of country-years in which presidents were in office who did not face a term limit and were eligible for a consecutive re-election. The remaining 870 cases constitute the donor pool of control units of country-years in which presidents faced term limits and so were not eligible for a consecutive re-election. If change from one category to another occurred during a year, that country-year was assigned the value corresponding to the longest duration. ${ }^{1}$ These three states are visualized in Figure 1.

The dependent variables are operationalized using three indices from the Varieties of Democracy (V-Dem) database (version 9) (Coppedge et al. 2019; Pemstein et al. 2019). The overall democratic performance is measured by the composite liberal democracy index (v2x_libdem), which indicates the extent to which civil liberties are protected, the rule of law is strong, the judiciary independent and/or checks and balances are effective. The second measure, vertical accountability index (v2x_veracc_osp), is based on the following components: an aggregate 
measure for the quality of elections, the percentage of enfranchised population and whether the chief executive is directly or indirectly elected, whether there are barriers to forming a party and how restrictive these are, as well as the degree to which opposition parties are independent of the ruling regime. The third dependent variable, horizontal accountability index (v2x_horacc_osp), operationalizes the extent to which the judiciary, the legislature and other state bodies (e.g. comptroller general, general prosecutor or ombudsman) hold the government to account and if they are likely to investigate and report potential irregularities and illegal or unethical activities by the executive (Coppedge et al. 2019; Lührmann, Marquardt and Mechkova 2020; Pemstein et al. 2019). It is important to note that none of these indexes includes the existence of term limits as an indicator entering the calculation of the index. This ensures that relationships between the existence of term limits and the quality of democracy and accountability presented in the models are not tautological.

Additionally, the Online Appendix provides tests using two more dependent variables measuring other dimensions of democratic governance. First, the Egalitarian Democracy Index (v2x_egaldem) indicates the extent to which the civil rights and freedoms are protected equally across social groups as well as how the resources are distributed in society (Coppedge et al. 2019; Pemstein et al. 2019). Second, the civil liberties index collected by Freedom House scores countries on their civil liberties from 1 (free) to 7 (not free) (Freedom House 2021).

The following analyses include information on five covariates that are used as control variables in the regression models to control for potential confounders. First, the level of party institutionalization was found to be a key causal factor in scrapping term limits by Latin American incumbent presidents because it presents an additional barrier to their personalistic behaviour (Kouba 2016). At the same time, however, party institutionalization has been linked to democratic outcomes (Dix 1992). Consequently, the relationship of term limits to the quality of democracy and accountability might be a result of more institutionalized party systems producing both more term-limited presidencies and higher-quality democratic governance. In order to control for this possibility, the models include a party institutionalization index - a political indicator capturing the level and depth of party organization, party links to civil society, and coherence of party platforms and ideologies (Coppedge et al. 2019; Pemstein et al. 2019). Second, a country's dependence and natural resource extraction has similarly been linked, on the one hand, to both the willingness and success of incumbent presidents in evading their term limits (Corrales 2009; Guliyev 2009; Kouba 2016) and, on the other hand, to declines in democratic quality due to the operation of the oil curse (Bergougui and Murshed 2020; Ross 2001). The models therefore control for the total natural resources rents (\% of GDP), a variable measuring the reliance of a country's economy on natural resources extraction (World Bank 2019c).

It is similarly important to control for variables measuring different dimensions of economic and social development. On the one hand, in countries with lower incomes and higher inequality, the value of holding office, and therefore the likelihood of term-limit removal, is expected to increase (Baturo 2010; Kouba 2016), while on the other hand, these might also be the countries where democratic governance is in the most danger (Burkhart and Lewis-Beck 1994; Houle 2009). The 
models therefore control for three additional variables. First, GDP per capita (in constant US\$) is calculated by averaging from the following four sources: ECLAC (Economic Commission for Latin America and the Caribbean 2019); Angus Maddison Historical Statistics (in 1990 international Geary-Khamis dollars) (Maddison 2010); IISH Data Collection Clio-infra Dataverse (in 1990 international Geary-Khamis dollars) (Bolt and van Zanden 2015); and World Bank Data - GDP per capita (World Bank 2019a). Second, economic inequality is measured by the Gini coefficient capturing the extent to which the income among households deviates from equal distribution. A value of 0 represents perfect equality and 100 represents perfect inequality. Averaged values from the following four sources were used: the Chartbook of Economic Inequality (Atkinson et al. 2017); World Bank Data - Gini Index (World Bank 2019b); the World Economic Forum's Inclusive Development Index (World Economic Forum 2018); and the Standardized World Income Inequality Database (Solt 2019). Third, the human development index (HDI) measures the development of a country as a summary measure of human development - that is, life expectancy, education and gross national income (GNI) per capita (United Nations Development Programme 2019).

Some models (see below) also include dependent variables lagged by one year. To deal with missing values of some of these covariates, we used the technique recommended for cross-national time-series data - an imputation model with polynomials of time using the Amelia package in $\mathrm{R}$ for data imputation, performing tests of the fitness of the imputation model by the over-imputation technique (see Honaker et al. 2011; Honaker and King 2010). In total, 500 imputed data sets with linear time effects with variation across countries were created. The descriptive statistics for all variables are available in the Online Appendix (Tables A1-A5).

\section{OLS models}

A series of OLS models are presented to estimate the effects of presidential re-electability on the three democratic outcomes - quality of democracy and horizontal and vertical accountability (see Tables $1-3$ ). We tested full model with all covariates by variance inflation factor in the Online Appendix (Table A6). To avoid multicollinearity, we decided to omit GDP per capita instead of HDI (regression models with GDP per capita are included in the Heckman selection models). To check for robustness, seven models for each dependent variable are estimated. The first six models represent simple outcome regressions on elected presidents only: (1) OLS during all years between 1945 and 2018; (2) OLS during the post-war years 1945-1989; (3) OLS using only country-years after the third democratization wave, 1990-2018; (4) GLS with fixed effects; (5) GLS with random effects within countries; and (6) GLS with random effects within countries with a lagged dependent variable.

Models 7 (with HDI as a covariate) and 8 (GDP per capita as a covariate) deal with a potential selection bias as the selection of cases is not random. The process of case selection could create correlation between the regressors and the error term. In this situation, the case selection left out non-elected governments (usually 
Table 1. OLS Models: Liberal Democracy Index as an Outcome

\begin{tabular}{|c|c|c|c|c|c|c|c|c|}
\hline & $\begin{array}{c}\text { OLS 1945- } \\
2018 \\
(1)\end{array}$ & $\begin{array}{c}\text { OLS 1945- } \\
1989 \\
(2)\end{array}$ & $\begin{array}{c}\text { OLS 1990- } \\
2018 \\
(3)\end{array}$ & $\begin{array}{l}\text { GLS with } \\
\text { fixed effects } \\
\text { (4) }\end{array}$ & $\begin{array}{l}\text { GLS with } \\
\text { random } \\
\text { effects } \\
(5)\end{array}$ & $\begin{array}{l}\text { GLS with } \\
\text { random } \\
\text { effects with } \\
\text { lagged dem. } \\
\text { (6) }\end{array}$ & $\begin{array}{l}\text { Heckman } \\
\text { selection with } \\
\text { HDI } \\
\text { (7) }\end{array}$ & $\begin{array}{l}\text { Heckman } \\
\text { selection with } \\
\text { GDP } \\
\text { (8) }\end{array}$ \\
\hline Treatment & $\begin{array}{c}-0.13^{\star \star \star} \\
(0.01)\end{array}$ & $\begin{array}{c}-0.15^{\star \star \star} \\
(0.02)\end{array}$ & $\begin{array}{c}-0.12^{\star \star \star} \\
(0.02)\end{array}$ & $\begin{array}{c}-0.10^{\star \star *} \\
(0.01)\end{array}$ & $\begin{array}{c}-0.10^{\star \star \star} \\
(0.01)\end{array}$ & $\begin{array}{c}-0.01^{\star \star \star} \\
(0.004)\end{array}$ & $\begin{array}{c}-0.13^{\star \star *} \\
(0.01)\end{array}$ & $\begin{array}{c}\left.-0.12^{\star \star \star}\right) \\
(0.02)\end{array}$ \\
\hline HDI & $\begin{array}{l}1.06^{\star \star \star} \\
(0.05)\end{array}$ & $\begin{array}{l}0.55^{\star \star \star} \\
(0.08)\end{array}$ & $\begin{array}{l}1.53^{\star \star \star} \\
(0.10)\end{array}$ & $\begin{array}{l}1.00^{\star \star \star} \\
(0.03)\end{array}$ & $\begin{array}{l}1.00^{\star \star \star} \\
(0.03)\end{array}$ & $\begin{array}{l}0.04^{\star \star \star} \\
(0.02)\end{array}$ & $\begin{array}{l}0.75^{\star \star \star} \\
(0.05)\end{array}$ & \\
\hline Natural resources (\% of GDP) & $\begin{array}{l}0.003^{\star \star} \\
(0.001)\end{array}$ & $\begin{array}{l}0.01^{\star \star \star} \\
(0.002)\end{array}$ & $\begin{array}{c}-0.003^{\star \star} \\
(0.001)\end{array}$ & $\begin{array}{l}0.01^{\star \star \star} \\
(0.001)\end{array}$ & $\begin{array}{l}0.01^{\star \star \star} \\
(0.001)\end{array}$ & $\begin{array}{c}-0.0002 \\
(0.0003)\end{array}$ & $\begin{array}{c}0.001 \\
(0.001)\end{array}$ & $\begin{array}{c}-0.005^{\star \star \star} \\
(0.002)\end{array}$ \\
\hline Gini & $\begin{array}{r}-0.001 \\
(0.001)\end{array}$ & $\begin{array}{c}-0.01^{\star \star \star} \\
(0.001)\end{array}$ & $\begin{array}{l}0.01^{\star \star \star} \\
(0.002)\end{array}$ & $\begin{array}{l}0.01^{\star \star \star} \\
(0.001)\end{array}$ & $\begin{array}{l}0.01^{\star \star \star} \\
(0.001)\end{array}$ & $\begin{array}{r}-0.0005 \\
(0.0003)\end{array}$ & $\begin{array}{c}0.001 \\
(0.001)\end{array}$ & $\begin{array}{c}-0.002^{\star \star} \\
(0.001)\end{array}$ \\
\hline Party institutionalization index & $\begin{array}{l}0.26^{\star \star \star} \\
(0.03)\end{array}$ & $\begin{array}{l}0.14^{\star \star \star} \\
(0.04)\end{array}$ & $\begin{array}{l}0.31^{\star \star \star} \\
(0.04)\end{array}$ & $\begin{array}{l}0.42^{\star \star \star} \\
(0.03)\end{array}$ & $\begin{array}{l}0.42^{\star \star \star} \\
(0.03)\end{array}$ & $\begin{array}{l}0.04^{\star \star \star} \\
(0.01)\end{array}$ & $\begin{array}{l}0.27^{\star \star \star} \\
(0.02)\end{array}$ & $\begin{array}{l}0.26^{\star \star \star} \\
(0.02)\end{array}$ \\
\hline Lag of liberal democracy index & & & & & & $\begin{array}{l}0.94^{\star \star \star} \\
(0.01)\end{array}$ & & \\
\hline GDP per capita & & & & & & & & $\begin{array}{l}0.0000^{\star \star \star} \\
(0.0000)\end{array}$ \\
\hline Constant & $\begin{array}{c}-0.31^{\star \star \star} \\
(0.07)\end{array}$ & $\begin{array}{l}0.42^{\star \star \star} \\
(0.11)\end{array}$ & $\begin{array}{c}-1.34^{\star \star \star} \\
(0.12)\end{array}$ & & $\begin{array}{c}-0.91^{\star \star \star} \\
(0.07)\end{array}$ & $\begin{array}{c}0.01 \\
(0.02)\end{array}$ & $\begin{array}{r}-0.05 \\
(0.09)\end{array}$ & $\begin{array}{l}0.49^{\star \star \star} \\
(0.07)\end{array}$ \\
\hline Observations & 1,067 & 575 & 492 & 1,067 & 1,067 & 1,067 & 1,332 & 1,332 \\
\hline$R^{2}$ & 0.60 & 0.57 & 0.52 & 0.68 & 0.68 & 0.96 & 0.65 & 0.63 \\
\hline Adjusted $R^{2}$ & 0.60 & 0.57 & 0.51 & 0.68 & 0.68 & 0.96 & 0.65 & 0.63 \\
\hline
\end{tabular}




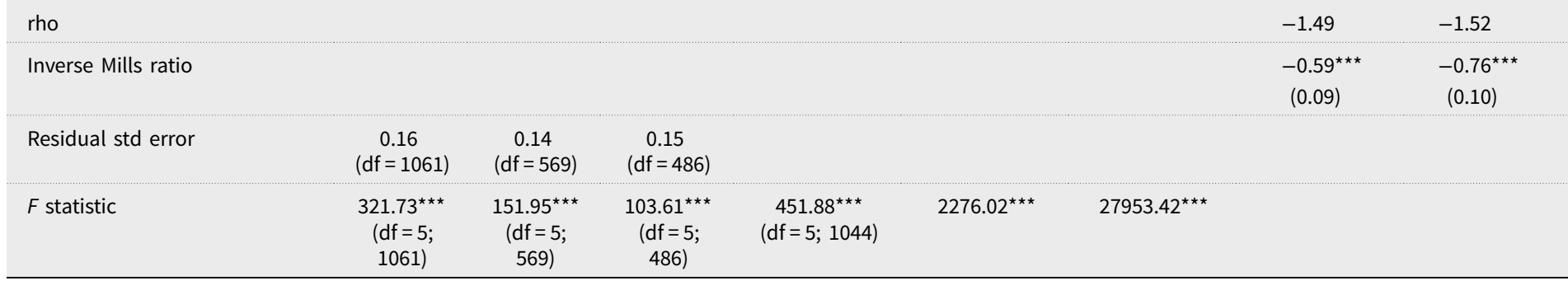

Note: ${ }^{*} p<0.1 ;{ }^{* *} p<0.05 ;{ }^{* \star} p<0.01$. 
Table 2. OLS Models: Vertical Accountability Index as an Outcome

\begin{tabular}{|c|c|c|c|c|c|c|c|c|}
\hline & $\begin{array}{l}\text { OLS 1945- } \\
2018 \\
(1)\end{array}$ & $\begin{array}{l}\text { OLS } 1945- \\
1989 \\
(2)\end{array}$ & $\begin{array}{l}\text { OLS } 1990- \\
2018 \\
\text { (3) }\end{array}$ & $\begin{array}{l}\text { GLS with fixed } \\
\text { effects } \\
\text { (4) }\end{array}$ & $\begin{array}{l}\text { GLS with } \\
\text { random effects } \\
\text { (5) }\end{array}$ & $\begin{array}{l}\text { GLS with random effects } \\
\text { with lagged dem. } \\
\text { (6) }\end{array}$ & $\begin{array}{l}\text { Heckman } \\
\text { selection with } \\
\text { HDI } \\
\text { (7) }\end{array}$ & $\begin{array}{l}\text { Heckman } \\
\text { selection with } \\
\text { GDP } \\
\text { (8) }\end{array}$ \\
\hline Treatment & $\begin{array}{l}-0.08^{\star \star \star} \\
(0.01)\end{array}$ & $\begin{array}{l}-0.10^{\star \star \star} \\
(0.02)\end{array}$ & $\begin{array}{l}-0.06^{\star \star \star} \\
(0.01)\end{array}$ & $\begin{array}{l}-0.07^{\star \star \star} \\
(0.01)\end{array}$ & $\begin{array}{l}-0.07^{\star \star \star} \\
(0.01)\end{array}$ & $\begin{array}{l}-0.02^{\star \star \star} \\
(0.005)\end{array}$ & $\begin{array}{l}-0.09^{\star \star \star} \\
(0.01)\end{array}$ & $\begin{array}{l}-0.08^{\star \star \star} \\
(0.01)\end{array}$ \\
\hline $\mathrm{HDI}$ & $\begin{array}{l}0.85^{\star \star \star} \\
(0.04)\end{array}$ & $\begin{array}{l}0.60^{\star \star \star} \\
(0.09)\end{array}$ & $\begin{array}{l}0.61^{\star \star \star} \\
(0.04)\end{array}$ & $\begin{array}{l}0.71^{\star \star \star} \\
(0.04)\end{array}$ & $\begin{array}{l}0.71^{\star \star \star} \\
(0.04)\end{array}$ & $\begin{array}{l}0.06^{\star \star \star} \\
(0.02)\end{array}$ & $\begin{array}{l}0.67^{\star \star \star} \\
(0.04)\end{array}$ & \\
\hline $\begin{array}{l}\text { Natural resources } \\
\text { ( } \% \text { of GDP) }\end{array}$ & $\begin{array}{l}0.002^{\star \star} \\
(0.001)\end{array}$ & $\begin{array}{l}0.01^{\star \star \star} \\
(0.002)\end{array}$ & $\begin{array}{c}-0.0002 \\
(0.001)\end{array}$ & $\begin{array}{c}-0.0005 \\
(0.001)\end{array}$ & $\begin{array}{c}-0.0004 \\
(0.001)\end{array}$ & $\begin{array}{c}-0.0002 \\
(0.0004)\end{array}$ & $\begin{array}{c}0.001 \\
(0.001)\end{array}$ & $\begin{array}{c}-0.0005 \\
(0.001)\end{array}$ \\
\hline Gini & $\begin{array}{c}-0.002^{\star \star} \\
(0.001)\end{array}$ & $\begin{array}{l}-0.01^{\star \star \star} \\
(0.002)\end{array}$ & $\begin{array}{l}0.01^{\star \star \star} \\
(0.001)\end{array}$ & $\begin{array}{r}-0.002 \\
(0.001)\end{array}$ & $\begin{array}{c}-0.001 \\
(0.001)\end{array}$ & $\begin{array}{c}-0.001^{\star \star \star} \\
(0.0004)\end{array}$ & $\begin{array}{c}-0.001 \\
(0.001)\end{array}$ & $\begin{array}{l}-0.003^{\star \star \star} \\
(0.001)\end{array}$ \\
\hline $\begin{array}{l}\text { Party } \\
\text { institutionalization } \\
\quad \text { index }\end{array}$ & $\begin{array}{l}0.23^{\star \star \star} \\
(0.03)\end{array}$ & $\begin{array}{l}0.32^{\star \star \star} \\
(0.04)\end{array}$ & $\begin{array}{l}0.10^{\star \star \star} \\
(0.02)\end{array}$ & $\begin{array}{l}0.42^{\star \star \star} \\
(0.03)\end{array}$ & $\begin{array}{l}0.42^{\star \star \star} \\
(0.03)\end{array}$ & $\begin{array}{l}0.05^{\star \star \star} \\
(0.01)\end{array}$ & $\begin{array}{l}0.23^{\star \star \star} \\
(0.02)\end{array}$ & $\begin{array}{l}0.32^{\star \star \star} \\
(0.02)\end{array}$ \\
\hline $\begin{array}{l}\text { Lag of vertical } \\
\text { accountability index }\end{array}$ & & & & & & $\begin{array}{l}0.87^{\star \star \star} \\
(0.01)\end{array}$ & & \\
\hline GDP per capita & & & & & & & & $\begin{array}{l}0.0000^{\star \star} \\
(0.0000)\end{array}$ \\
\hline Constant & $\begin{array}{l}0.21^{\star \star \star} \\
(0.06)\end{array}$ & $\begin{array}{l}0.43^{\star \star \star} \\
(0.12)\end{array}$ & $\begin{array}{c}0.02 \\
(0.06)\end{array}$ & & $\begin{array}{l}0.17^{\star \star} \\
(0.07)\end{array}$ & $\begin{array}{l}0.09^{\star \star \star} \\
(0.03)\end{array}$ & $\begin{array}{l}0.35^{\star \star \star} \\
(0.07)\end{array}$ & $\begin{array}{l}0.90^{\star \star \star} \\
(0.07)\end{array}$ \\
\hline Observations & 1,067 & 575 & 492 & 1,067 & 1,067 & 1,067 & 1,332 & 1,332 \\
\hline$R^{2}$ & 0.58 & 0.49 & 0.46 & 0.61 & 0.61 & 0.92 & 0.60 & 0.52 \\
\hline Adjusted $R^{2}$ & 0.58 & 0.49 & 0.45 & 0.60 & 0.61 & 0.92 & 0.60 & 0.52 \\
\hline rho & & & & & & & -1.36 & -1.50 \\
\hline Inverse Mills ratio & & & & & & & $\begin{array}{l}-0.34^{\star \star \star} \\
(0.06)\end{array}$ & $\begin{array}{l}-0.61^{\star \star \star} \\
(0.09)\end{array}$ \\
\hline
\end{tabular}




\begin{tabular}{|c|c|c|c|c|c|c|}
\hline Residual std error & $\begin{array}{c}0.14 \\
(\mathrm{df}=1061)\end{array}$ & $\begin{array}{c}0.16 \\
(\mathrm{df}=569)\end{array}$ & $\begin{array}{c}0.07 \\
(\mathrm{df}=486)\end{array}$ & & & \\
\hline F statistic & $\begin{array}{c}290.54^{\star \star \star} \\
(\mathrm{df}=5 \\
1061)\end{array}$ & $\begin{array}{c}110.51^{\star \star \star} \\
(\mathrm{df}=5 ; 569)\end{array}$ & $\begin{array}{c}81.56^{\star \star \star} \\
(\mathrm{df}=5 ; 486)\end{array}$ & $\begin{array}{c}327.14^{\star \star \star} \\
(\mathrm{df}=5 ; 1044)\end{array}$ & $1652.22^{\star \star \star}$ & $12781.36^{\star \star \star}$ \\
\hline
\end{tabular}

Note: ${ }^{\star} p<0.1 ;{ }^{\star \star} p<0.05 ;{ }^{\star \star \star} p<0.01$. 
Table 3. OLS Models: Horizontal Accountability Index as an Outcome

\begin{tabular}{|c|c|c|c|c|c|c|c|c|}
\hline & $\begin{array}{c}\text { OLS 1945- } \\
2018 \\
(1)\end{array}$ & $\begin{array}{c}\text { OLS 1945- } \\
1989 \\
(2)\end{array}$ & $\begin{array}{c}\text { OLS } 1990- \\
2018 \\
(3)\end{array}$ & $\begin{array}{l}\text { GLS with fixed } \\
\text { effects } \\
\text { (4) }\end{array}$ & $\begin{array}{l}\text { GLS with } \\
\text { random effects } \\
\text { (5) }\end{array}$ & $\begin{array}{l}\text { GLS with random } \\
\text { effects with lagged } \\
\text { dem. } \\
\text { (6) }\end{array}$ & $\begin{array}{l}\text { Heckman } \\
\text { selection with } \\
\text { HDI } \\
\text { (7) }\end{array}$ & $\begin{array}{l}\text { Heckman } \\
\text { selection with } \\
\text { GDP } \\
\text { (8) }\end{array}$ \\
\hline Treatment & $\begin{array}{l}-0.24^{\star \star \star} \\
(0.02)\end{array}$ & $\begin{array}{l}-0.27^{\star \star \star} \\
(0.03)\end{array}$ & $\begin{array}{l}-0.20^{\star \star \star} \\
(0.02)\end{array}$ & $\begin{array}{l}-0.16^{\star \star \star} \\
(0.01)\end{array}$ & $\begin{array}{l}-0.16^{\star \star \star} \\
(0.01)\end{array}$ & $\begin{array}{c}-0.02^{\star \star} \\
(0.01)\end{array}$ & $\begin{array}{l}-0.24^{\star \star \star} \\
(0.02)\end{array}$ & $\begin{array}{l}-0.22^{\star \star \star} \\
(0.02)\end{array}$ \\
\hline $\mathrm{HDI}$ & $\begin{array}{l}1.00^{\star \star *} \\
(0.07)\end{array}$ & $\begin{array}{l}0.36^{\star \star \star} \\
(0.13)\end{array}$ & $\begin{array}{l}1.58^{\star \star \star} \\
(0.13)\end{array}$ & $\begin{array}{l}0.69^{\star \star \star} \\
(0.05)\end{array}$ & $\begin{array}{l}0.70^{\star \star \star} \\
(0.05)\end{array}$ & $\begin{array}{c}0.04^{\star} \\
(0.02)\end{array}$ & $\begin{array}{l}0.73^{\star \star \star} \\
(0.07)\end{array}$ & \\
\hline $\begin{array}{l}\text { Natural resources } \\
(\% \text { of GDP) }\end{array}$ & $\begin{array}{l}0.004^{\star \star \star} \\
(0.001)\end{array}$ & $\begin{array}{l}0.01^{\star \star \star} \\
(0.002)\end{array}$ & $\begin{array}{l}-0.004^{\star \star} \\
(0.002)\end{array}$ & $\begin{array}{r}0.0001 \\
(0.002)\end{array}$ & $\begin{array}{r}0.0002 \\
(0.002)\end{array}$ & $\begin{array}{l}-0.001 \\
(0.0005)\end{array}$ & $\begin{array}{l}0.003^{\star} \\
(0.002)\end{array}$ & $\begin{array}{r}-0.002 \\
(0.002)\end{array}$ \\
\hline Gini & $\begin{array}{r}-0.002 \\
(0.002)\end{array}$ & $\begin{array}{l}-0.01^{\star \star \star} \\
(0.002)\end{array}$ & $\begin{array}{l}0.02^{\star \star \star} \\
(0.002)\end{array}$ & $\begin{array}{c}-0.0002 \\
(0.001)\end{array}$ & $\begin{array}{c}-0.0002 \\
(0.001)\end{array}$ & $\begin{array}{l}-0.001 \\
(0.0005)\end{array}$ & $\begin{array}{c}-0.0003 \\
(0.002)\end{array}$ & $\begin{array}{c}-0.003^{\star \star} \\
(0.001)\end{array}$ \\
\hline $\begin{array}{l}\text { Party } \\
\text { institutionalization } \\
\text { index }\end{array}$ & $\begin{array}{l}0.26^{\star \star \star} \\
(0.04)\end{array}$ & $\begin{array}{l}0.25^{\star \star \star} \\
(0.06)\end{array}$ & $\begin{array}{l}0.16^{\star \star \star} \\
(0.05)\end{array}$ & $\begin{array}{l}0.56^{\star \star \star} \\
(0.04)\end{array}$ & $\begin{array}{l}0.55^{\star \star \star} \\
(0.04)\end{array}$ & $\begin{array}{l}0.03^{\star \star \star} \\
(0.01)\end{array}$ & $\begin{array}{l}0.27^{\star \star \star} \\
(0.04)\end{array}$ & $\begin{array}{l}0.28^{\star \star \star} \\
(0.04)\end{array}$ \\
\hline $\begin{array}{l}\text { Lag of horizontal } \\
\text { accountability index }\end{array}$ & & & & & & $\begin{array}{l}0.94^{\star \star \star} \\
(0.01)\end{array}$ & & \\
\hline GDP per capita & & & & & & & & $\begin{array}{l}0.0000^{\star \star \star} \\
(0.0000)\end{array}$ \\
\hline Constant & $\begin{array}{r}-0.06 \\
(0.10)\end{array}$ & $\begin{array}{l}0.76^{\star \star \star} \\
(0.17)\end{array}$ & $\begin{array}{l}-1.35^{\star \star \star} \\
(0.17)\end{array}$ & & $\begin{array}{r}-0.14 \\
(0.10)\end{array}$ & $\begin{array}{c}0.03 \\
(0.03)\end{array}$ & $\begin{array}{c}0.18 \\
(0.11)\end{array}$ & $\begin{array}{l}0.71^{\star \star \star} \\
(0.10)\end{array}$ \\
\hline Observations & 1,067 & 575 & 492 & 1,067 & 1,067 & 1,067 & 1,332 & 1,332 \\
\hline$R^{2}$ & 0.46 & 0.48 & 0.40 & 0.49 & 0.49 & 0.95 & 0.49 & 0.47 \\
\hline Adjusted $R^{2}$ & 0.46 & 0.47 & 0.39 & 0.48 & 0.49 & 0.95 & 0.49 & 0.46 \\
\hline rho & & & & & & & -1.33 & -1.43 \\
\hline
\end{tabular}




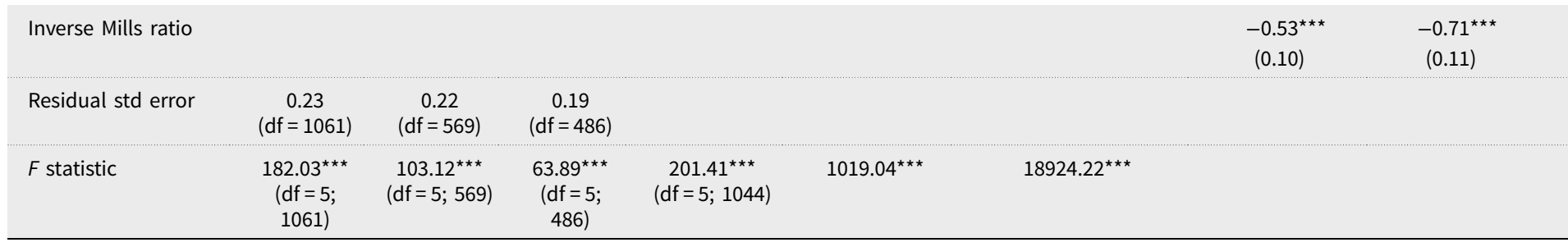

Note: ${ }^{\star} p<0.1 ;{ }^{* \star} p<0.05 ;{ }^{* \star *} p<0.01$. 
military governments in authoritarian regimes), so the country-years with military government will be correlated with (non-)democratic outcomes. To avoid sample selection bias and endogeneity in the analysis, Heckman sample selection models were used (Heckman 1976). In the first stage, a value of 0 was assigned to countryyears in which rulers other than elected presidents were heads of state, and 1 to the rest of the country-years. At this first stage a probit equation estimates the selection process and the results from this equation provide a variable that captures the selection effect in the outcome equation for the second stage (i.e. the inverse Mills ratio). ${ }^{2}$ The independent variable in the second stage among these cases with elected presidents was the re-electability status - with a value of 0 for country-years with term-limited presidents in power and 1 for those who were immediately re-electable. The sampleSelection package in $\mathrm{R}$, which presents a two-step Heckman estimation that corrects for non-random sample selection, was used (Toomet and Henningsen 2008).

The coefficient estimates of the re-electability status from these alternative models, including the Heckman selection models, exhibit remarkable stability. The findings from Heckman selection models also confirm that the results of the main models are unaffected by dropping observation of country-years in with non-elected leaders. We tested models with fixed and random effects and there is little difference between them. The estimates from all models show a negative and highly significant relationship between the treatment and the dependent variables. Having presidents re-electable for another consecutive term negatively affected the overall quality of liberal democracy as well as horizontal and vertical accountability in Latin America between 1945 and 2018. The results also suggest that horizontal accountability is most vulnerable to presidents with unlimited terms. All the treatment coefficients are statistically significant at the 0.01 level (with one exception: the treatment coefficient for the horizontal accountability in the GLS model with random effects with lagged index is statistically significant at the 0.05 level). There is also a strong positive association between the three outcome variables and the control variables used in the models. Higher levels of party institutionalization, for example, imply a higher quality of democracy and vertical and horizontal accountability. Robustness tests in the Online Appendix (Tables A9-A11) disaggregate the main independent variable into three dummy variables to understand the differential effect of a mere ban on a consecutive re-election beyond the following term and a complete removal of term limits. They suggest that democracy and accountability are indeed hindered by the complete removal of term limits over and above the effect of a possibility of only a single consecutive re-election. A further robustness test using sensitivity analysis is also consistent with this interpretation (Table A9.1 in the Online Appendix).

The Online Appendix also includes further robustness tests that check for the presumed positive effects of the possibility of re-election on democratic outcomes due to the operation of vertical accountability. By disaggregating the main dependent variable, these models test the association to democratic outcomes of first-term presidents eligible for a single consecutive re-election compared to presidents in their second (and last) term. Country-years during such second terms indeed feature weaker democratic and accountability outcomes than country-years during the 
first terms. On the whole, however, even these first terms of re-electable presidents feature weaker democratic outcomes than under fully term-limited presidents.

\section{The effects of term-limit evasion on democracy and accountability, 1983-2018}

Is democracy affected if the incumbent president changes the term-limit rules? This question is examined using the synthetic control method. We restrict the analysis only to third wave democracies (i.e. cases of term-limit evasion after 1983) in order to maximize comparability within a single time frame. Heralded as the most important innovation in the policy evaluation literature in the last 15 years (Athey and Imbens 2017: 9), the synthetic control method builds on the difference-in-differences approach by seeking to understand the effect of a policy intervention. Its advantage over the difference-in-differences methods is that it relaxes the parallel trends assumption and provides dynamic estimates of the average effects (Olper et al. 2018). Unlike the difference-in-differences estimation, the estimates of causal effects are unique for any given case. This is an important improvement over pooled regression models for panel data because it allows us to gauge casual identification separately for each country in the sample (De Kadt and Wittels 2019). It is therefore suitable for those contexts where the effects are expected to be heterogenous across the investigated units (Olper et al. 2018).

The synthetic control method (Abadie et al. 2010, 2015) matches pre-treatment covariates and outcomes between the treated units and a set of control units and it constructs a synthetic control unit as the counterfactual for the treated unit by reweighting the control units (Xu 2017: 58). The synthetic control group outcomes should match the treated unit outcomes within the pre-intervention years, and is expected to project relevant counterfactuals for the treated unit into the post-treated years. Research designs in comparative politics have used this feature to address endogeneity concerns stemming from reverse causation (Singh 2019: 37), a situation that potentially also characterizes the relationship between term limits and democracy.

The models are estimated using the synthetic control method in $\mathrm{R}$ package gsynth, which implements the generalized synthetic control method. This package imputes counterfactuals for each treated unit using data from the donor pool $\mathrm{Xu}$ 2017). Unlike the original synthetic control method, it allows more than one treatment year, so it can be used with unbalanced panel data with different treatment kicks. It also provides other estimates, such as standard errors and confidence intervals, which improves efficiency and interpretability (Xu 2017). The matrix completion method is used (Athey and Imbens 2017), which runs a different algorithm and regularization scheme and takes advantage of the treatment group information in the pre-treatment period (Xu 2017). In the Online Appendix (Section 5.2) we also provide other results using the expectation maximization (EM) method algorithm (Gobillon and Magnac 2016; Xu 2017).

The analysis based on the generalized synthetic control method uses a data set of 596 country-years from the 18 Latin American countries between 1983 and 2018 (see Figure 2). Because some authoritarian regimes were still in place during some 
(a)

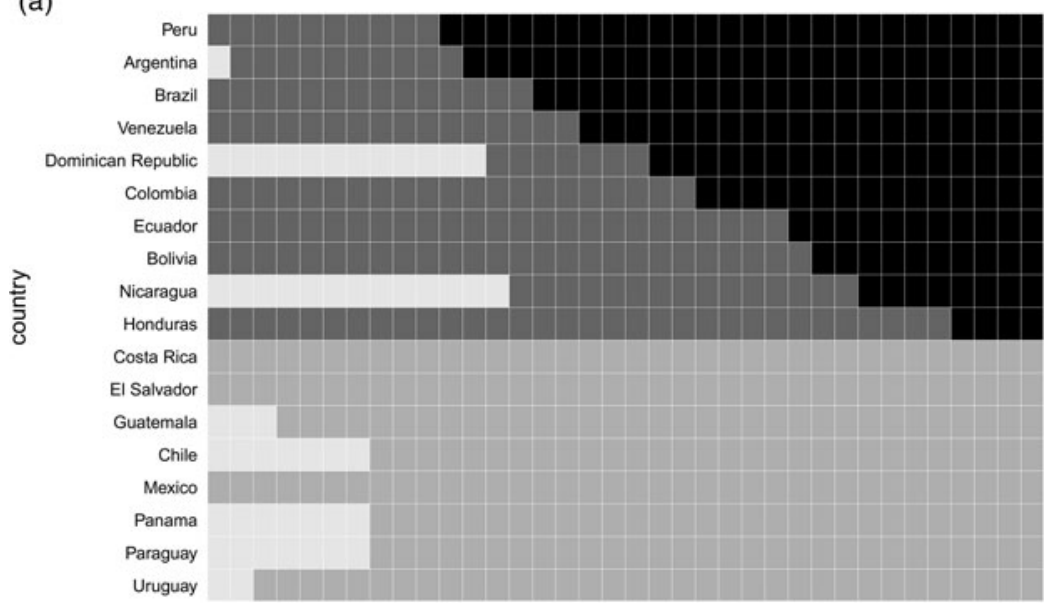

,

year

$\begin{array}{lll}\text { Missing } & \text { Controls } \\ \text { Treated (Pre) } & \text { Treated (Post) }\end{array}$

(b)

Re-election reform and Liberal Democracy Index

Always Under Control

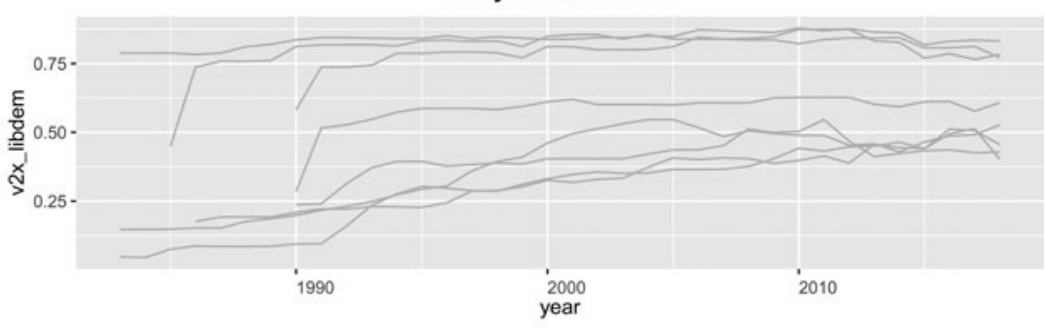

Treatment Status Changed

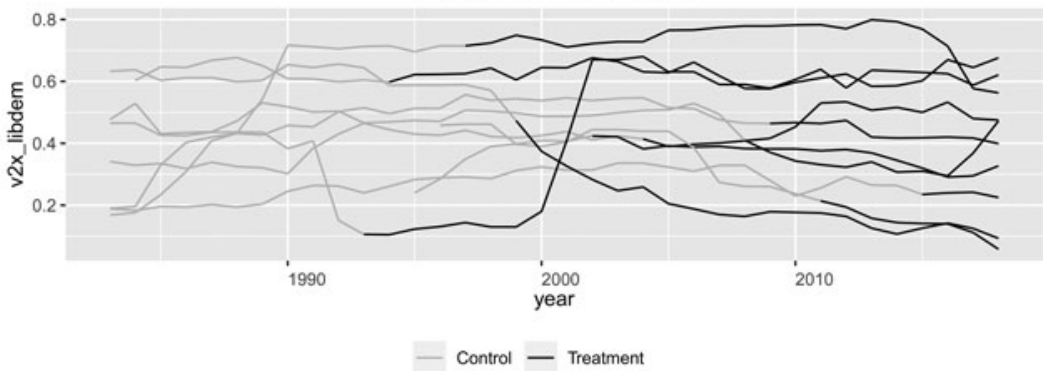

Figure 2. Latin American Countries by Treatment Status, 1983-2018 
Table 4. Average Treatment Effect of Term-Limit Evasion on Three Democratic Outcomes

\begin{tabular}{lccccc}
\hline & ATT & S.E. & Cl-lower & Cl-upper & $p$-value \\
\hline Liberal democracy index & -0.1278 & 0.0636 & -0.2666 & -0.0198 & 0.0260 \\
\hline Vertical accountability index & -0.0703 & 0.0288 & -0.1261 & -0.0137 & 0.0120 \\
\hline Horizontal accountability index & -0.1898 & 0.0949 & -0.3963 & -0.0402 & 0.0080 \\
\hline
\end{tabular}

of the early years, these were removed from the data set because they are not comparable: Argentina in 1983 (non-democratic regime), Dominican Republic 1983-1994 (until 1994 there was no term limit), Guatemala 1983-1985 (non-democratic regime), Chile, Paraguay and Panama 1983-1989 (non-democratic regimes), Nicaragua 1983-1995 (there was no term limit between 1987 and 1995), Uruguay 19831984 (non-democratic regime).

In the first step, we coded the independent variable (treatment, in this case the occurrence of term-limit reform) with a binary indicator. The value 1 was assigned to the post-treatment period (i.e. country-years following the reform that allowed for re-electability of a president). The value 0 was assigned to the country-years of the pre-treatment period and all yearly observations in countries with no reform (control units). There are 10 treated countries, where the treatment kicks in at different times. The remaining eight non-treated countries constitute the donor pool of country-years in which no permissive reform during 1983-2018 was observed.

In the next step, the model with the outcome variables (liberal democracy, horizontal and vertical accountability), the treatment indicator (treatment $=1$ ) and five observed covariates (GDP per capita, Gini coefficient, HDI, total natural resources rents \% of GDP and party institutionalization index) is estimated. Using the gsynth algorithm, we choose two-way fixed effects with cross-validation procedure and uncertainty estimates (standard errors and confidence levels). We also set a minimum value of the pre-treatment period ( $>7$ years), so that no country is removed from the model.

Table 4 shows the average treatment effect on the treated (ATT) averaged over all periods. Tables A19-A24 in the Online Appendix also include supplementary information: the ATT by period (including pre-treatment periods); and the coefficients of the time-varying covariates.

Plots for the estimated treatment effects for the entire set of Latin American countries are presented in Figure 3 and plots for individual countries in Figure 4. This displays the plots of the estimated average treatment effect on the treated units and predicted $\mathrm{Y}(0)$ s (treated and counterfactuals) for each country that experienced term-limit evasion. Because the re-election reforms in these countries kick in at different years, the gsynth algorithm realigns the $\mathrm{x}$-axis based on the timing of the treatment (time relative to treatment).

The plots for the entire set of Latin American countries display the negative effects of term-limit removal on all three outcomes, which corresponds with the earlier regression and matching results. The horizontal accountability (ATT = $-0.19)$ is damaged more by term-limit evasion than is vertical accountability $(\mathrm{ATT}=-0.07)$ or liberal democracy $(\mathrm{ATT}=-0.12)$. 
(a)

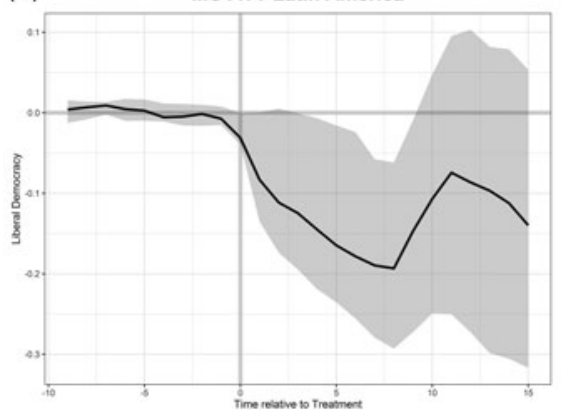

(c)

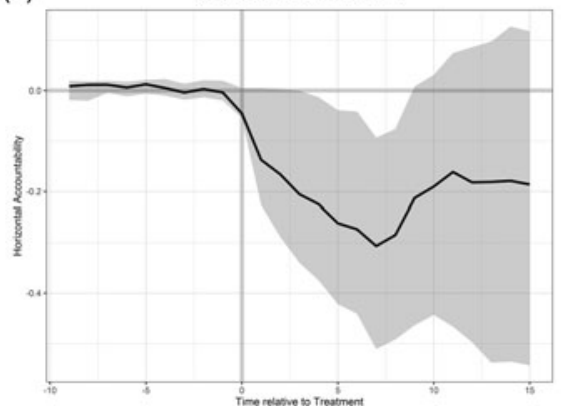

(e)

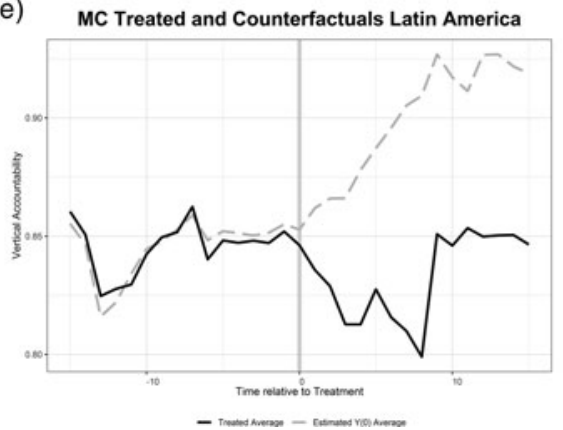

(b) MC ATT Latin America

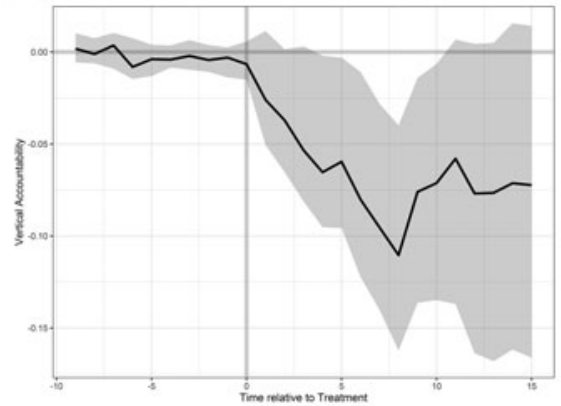

(d)

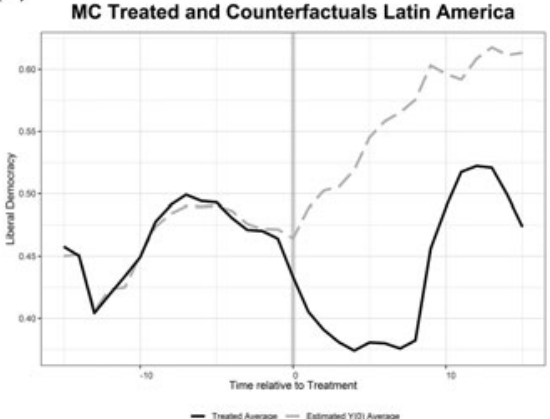

(f)

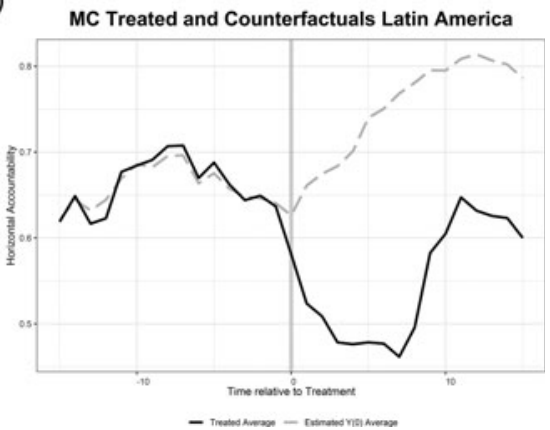

Figure 3. The Effect of Term-Limit Evasion on the Three Democratic Outcomes in Latin America, 1983-2018

In only two countries - Peru and Brazil - do the post-treatment values of the liberal democracy index surpass those of their respective synthetic cases, and even there only for a limited period of time and in both cases with a limited effect size. Peru, it must be noted, reversed the term-limit contravention by President Alberto Fujimori in 2000, reverting to a non-consecutive rule, so most of its posttreatment evolution actually took place under non-re-election laws. The small differences between the observed and counterfactual paths in some countries may also be attributable to the mode of term-limit removal. That is, the democratic effect of term-limit removal may be conditional on the circumstances under which such 

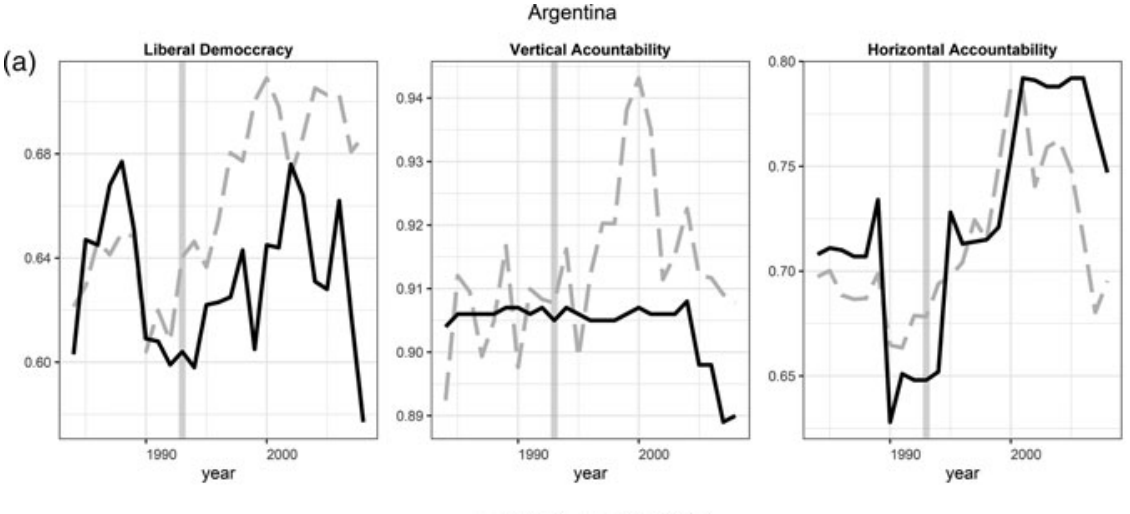

(b)
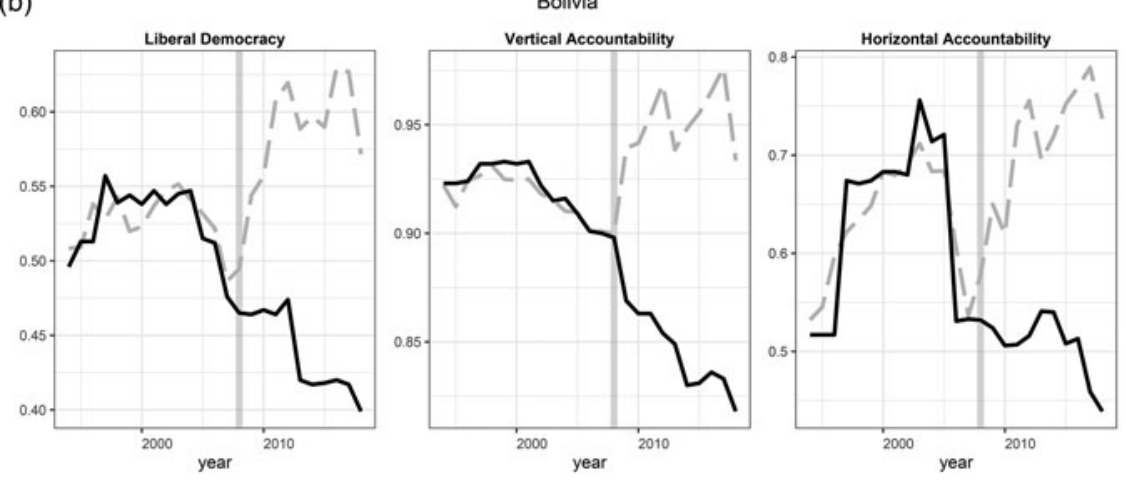

- Treated - Estimated Y $(0)$

(c)
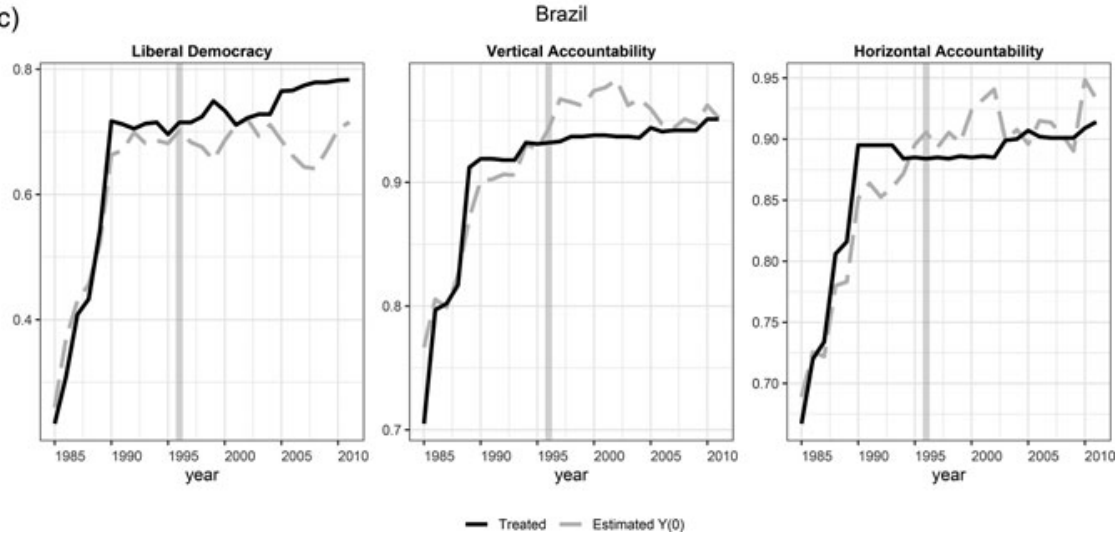

Figure 4. The Effect of Term-Limit Evasion on the Three Democratic Outcomes by Latin American Countries 
(d)

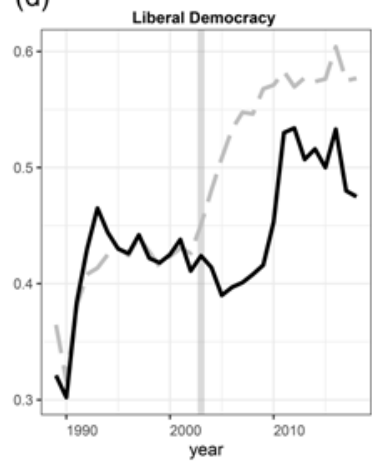

(e)

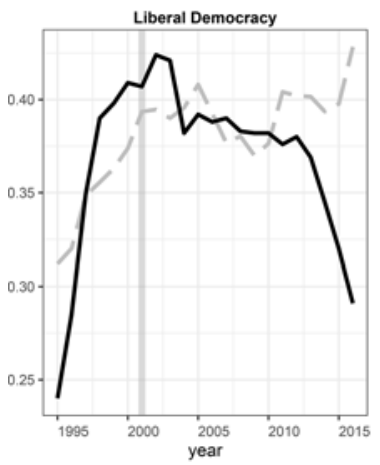

(f)

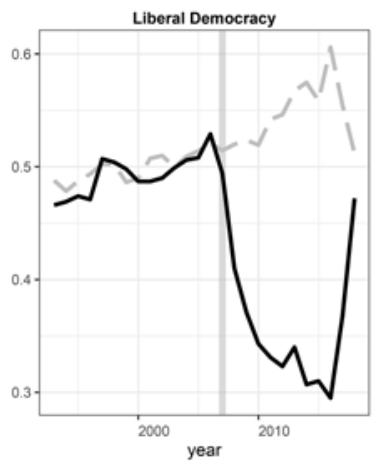

Colombia

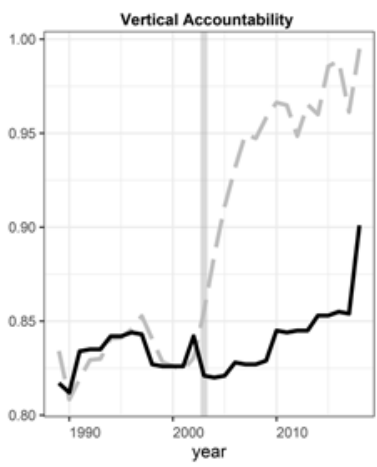

- Treated - Estimated $Y(0)$

\section{Dominican Republic}
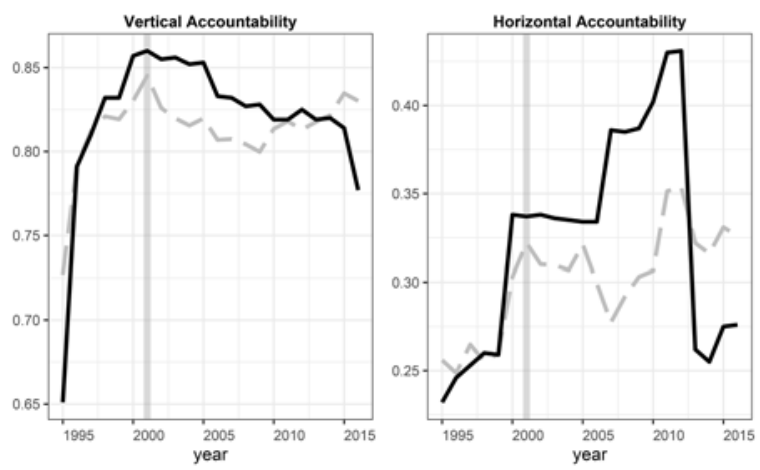

- Treated - Estimated $Y(0)$

Ecuador
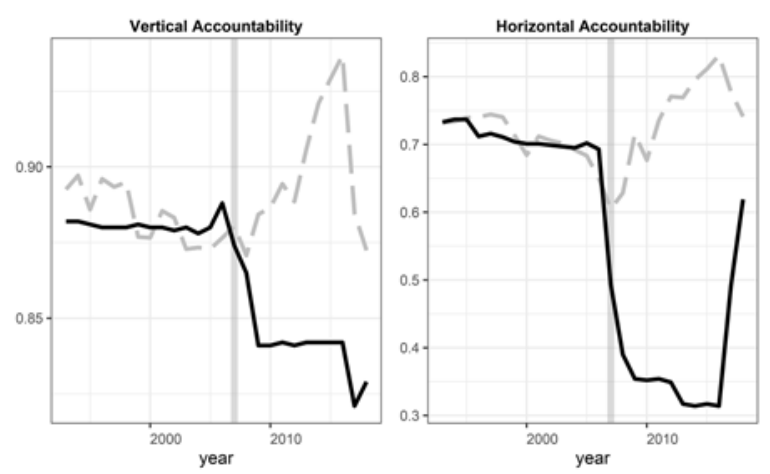

- Treated - Estimated $Y(0)$

Figure 4. Continued. 
(g)

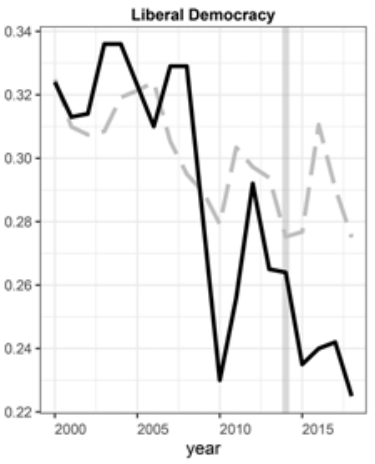

(h)

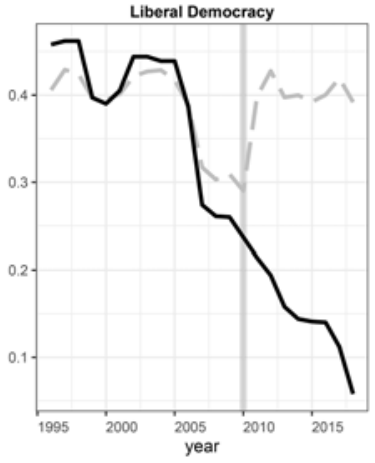

(i)

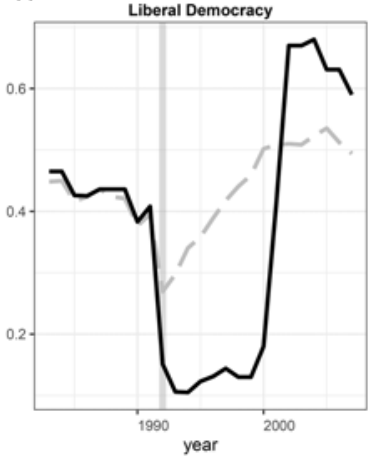

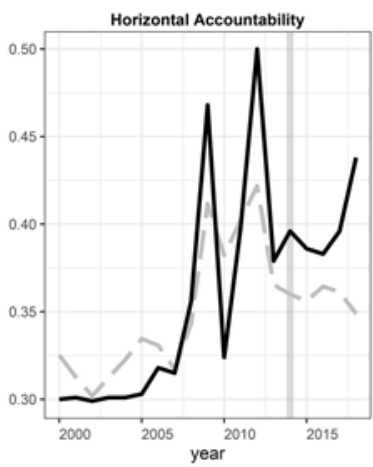

- Treated - Estimated $Y(0)$

Nicaragua
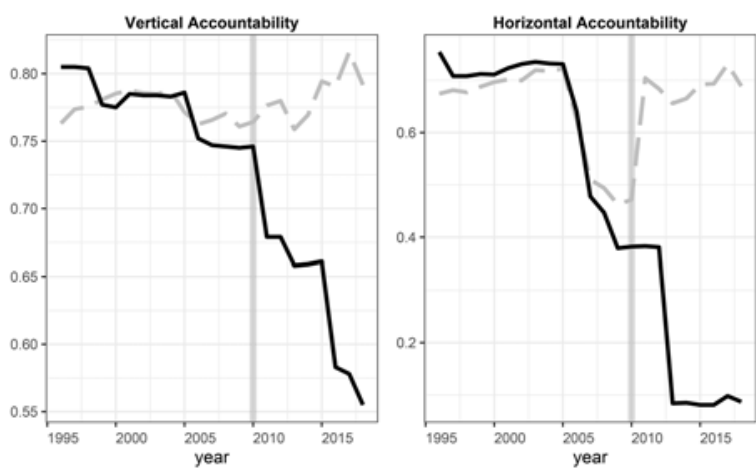

- Treated - Estimated $Y(0)$

Peru
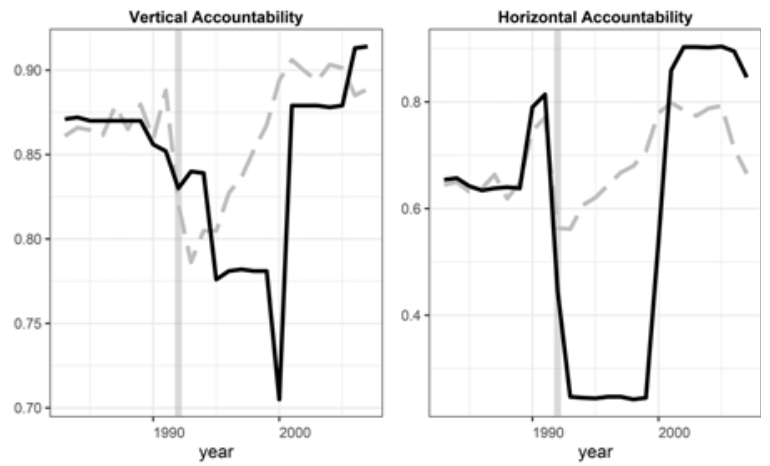

- Treated - Estimated Y(0)

Figure 4. Continued. 


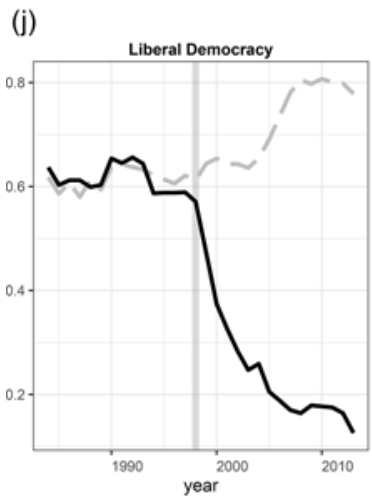

- Treated - Estimated $Y(0)$

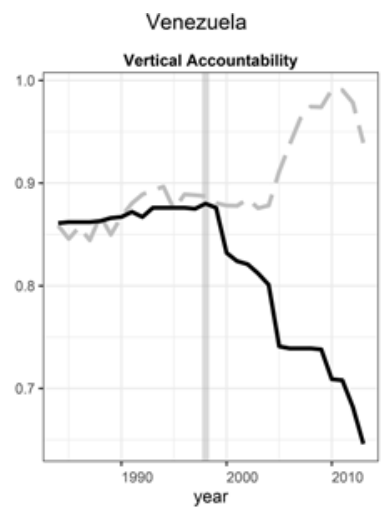

- Treated - Estimated $Y(0)$

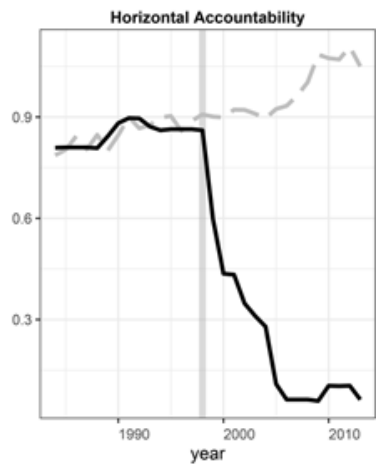

- Treated - Estimated $Y(0)$

Figure 4. Continued.

reform originated. Whether re-election was instituted through court rulings, congressional approval, constituent assembly or referenda (see Sánchez 2013), the extent of its popular approval or whether the opposition parties consented to the reform, may all be relevant considerations. The Argentine negotiated term-limit relaxation in 1994, which involved the consent of the opposition parties in the constituent assembly in return for fulfilling some of their demands, and the smooth 1997 reform in Brazil, which enjoyed large public and congressional support even among opposition parties (Goertzel 1999), are examples of rather unique paths which have not produced democratic deterioration.

The largest drop in liberal democracy levels relative to the counterfactual scenario occurred in the four countries with radical leftist presidents - Bolivia, Ecuador, Nicaragua and Venezuela. Prior to their rise to power, all four were characterized by extensive delegitimization of previous regimes and a lack of stable and coherent leftist parties. With the exception of Ecuador, these presidents (Evo Morales, Daniel Ortega and Hugo Chávez) sought to extend their stay in power beyond their first term-limit relaxation, and Morales and Ortega did so in a constitutionally dubious way. But the large net effects on horizontal accountability in countries such as Colombia suggest that democratic deterioration in the aftermath of term-limit removal is not unique to radical leftist presidencies.

Re-election reforms are often accompanied by other major constitutional reforms which could also affect the democratic trajectories of those countries. In some cases, term-limit removal resulted from the adoption of new constitutions (e.g. Argentina, Bolivia, Ecuador, Venezuela), while this was an isolated reform in other countries (e.g. Brazil, Honduras, Nicaragua, Colombia). There does not seem to be a pattern as both types of term-limit evasion have resulted in deep democratic deterioration in some cases and a lack of meaningful effect in others. For example, the abolition of term limits in Nicaragua was a two-step process as the incumbent Sandinista president Daniel Ortega first removed the absolute proscription of consecutive re-election in 2009 and then moved to fully undo all term 
limits in 2014 (Close 2019). Both were isolated constitutional reforms and both helped fragment the opposition, reduce political competition and gradually move the country towards an authoritarian regime (Buben and Kouba 2020). Compare this to Bolivia, where the term-limit relaxation by Evo Morales was originally adopted as part of the new constitution in 2009, but which developed along a similar path to Nicaragua as President Morales ignored the original two-term limit (and the results of the 2016 referendum where a majority of Bolivians rejected another term extension). Similar to Nicaragua, this term-limit evasion resulted in an increasingly authoritarian exercise of power and violent confrontations with the opposition in 2019 (Levitsky and Murillo 2020). Unlike Ortega, whose authoritarian tactics secured his political survival even after a violent confrontation with an opposition movement in 2018, Morales was ousted from power under coup-like circumstances amid allegations of voter fraud following his re-re-election attempt in 2019 (Wolff 2020).

\section{Conclusion}

We asked two related but distinct research questions. First, does having a permissive re-election rule reduce or help the quality of democracy relative to periods in which presidents are not eligible for immediate re-election? Second, does changing the re-election rule to allow the incumbent to run for a consecutive term undermine or help the country's democracy? There is very little to suggest that term-limit removal and the possibility of re-election help democracy in any discernible way. The presented models report a negative relationship between the existence of presidential re-election rules and the level of liberal democracy, but also horizontal and vertical accountability. The success of the term-limit evasion attempt is furthermore strongly related to long-term democratic erosion in all three of these dimensions, as evidenced by the synthetic control method. The fact that in no countries did the synthetic values of the democracy and accountability indices significantly surpass the observed values (but were significantly lower in most) strongly suggests an overall independent negative effect of term-limit evasion on democracy.

An established theoretical tradition emphasizes that the ability of incumbents to run for re-election improves vertical accountability and enhances democratic governance. We indeed found some support that the second consecutive (and last) terms of presidents are associated with a weaker democratic outcome than their first terms. This is consistent with the proposition that presidents become less accountable in their second (and last) terms. On the whole, however, even these first terms of re-electable presidents feature weaker democratic outcomes than when there is a fully term-limited president. Presidential re-election significantly weakens vertical accountability in Latin America, although on average to a lesser degree than horizontal accountability does.

For some, the vertical accountability faced by non-term-limited presidents is of such a high importance for democratic governance that institutional reforms other than term limits should be sought instead (Cheibub and Medina 2019). Their aim should be to regulate the incumbency advantage rather than abolish it. They include improvements to electoral accountability such as stricter regulation of campaign finance, fair distribution of public campaign funding, access to media and 
strengthening of agencies that oversee electoral campaigns (Cheibub and Medina 2019: 531). Our results put these recommendations into perspective. The introduction of similar reforms to promote vertical accountability is certainly laudable, but we provide sufficient reason to doubt if they can be effectively put in place, particularly in settings where presidents are allowed to run for immediate re-election (i.e. where these reforms are most needed). Such reforms require horizontal accountability, that is, the existence of autonomous institutions - oversight agencies, courts and so on - to which the presidents are held accountable. But these are precisely the sort of institutions whose autonomy and effectiveness in checking the president are damaged by the lack of presidential term limits in the first place. Term-unlimited presidents all too often trample on their autonomy. Because the damage to horizontal and vertical accountability from the existence of immediate re-election goes hand in hand, it is unlikely that simple reforms of campaign funding and organizing undo the nefarious effects of re-election on democracy. Such reforms are unlikely to be neutral but are very likely to skew the playing field in favour of the incumbent president.

Our results also suggest that in most countries term-limit evasion does have an effect on the level of democracy. An opposing interpretation of term limits would emphasize the endogenous relationship between consecutive re-election and democracy. For example, the lack of political competition is a strong predictor of termlimit evasion (McKie 2019), and so are the challenges to horizontal accountability through weak judicial independence (Kouba 2016). It would be tempting to conclude that term limits are repealed in countries where democracy is already eroded, and that this explains the association between the lack of term limits and (non-) democracy. The synthetic control method, although an improvement over standard regression techniques because it allows us to gauge the causal identification separately for each country and provides dynamic estimates of the causal effects, solves this issue only partially. Still, the fact that in no countries did the synthetic values of the democracy and accountability indices significantly surpass the observed values (but were significantly lower in most) strongly suggests an overall independent negative effect of term-limit evasion on democracy.

Term limits are not a panacea for a functioning democracy. Term limits have historically existed in both democratic and authoritarian countries. The Somoza clan in Nicaragua presided over a personalist dictatorship (1936-1979) without the need to scrap term limits. Instead term limits were used as an instrument of authoritarian rule by the Somozas, who formally handed over the presidential office to a safe replacement three times without relinquishing de facto power - a practice Luis Somoza derided as 'changing the monkey' (Close 2019). The enduring Mexican 'perfect dictatorship' prior to 2000 was not only compatible with strict term limits but these were also central to its interacting with other institutional features (Klesner 2019). Despite such episodes, the overall balance across Latin America indicates that between 1945 and 2018 democracy has been better off when term limits were in place than when they were not. This association remains strong even after controlling for other determinants of democracy. Not only are countries that employ them better democracies, but also the attempts to repeal them do not help - rather, they are either neutral or outright detrimental to democracy. 
Supplementary material. The supplementary material for this article can be found at https://doi.org/10. 1017/gov.2021.51.

Acknowledgements. The work was supported by the IRT Research Grant provided by the Philosophical Faculty, University of Hradec Králové (Formal and Informal Institutions and Their Impact on Political Representation).

\section{Notes}

1 For example, in April 1969, Bolivia's elected president Barrientos died in a helicopter crash and was succeeded by Vice President Siles. In September Siles was overthrown by a coup d'état; i.e. most of the year, unelected leaders were in office. We coded Bolivia in 1969 as a missing case with a non-elected president. The dates for the beginning and the end of the mandates are coded according to taking office, and not by the date of the election.

2 In the Online Appendix (Tables A1-A5) more Heckman selection coefficients for all our outcomes in each selection phase are included.

\section{References}

Abadie A, Diamond A and Hainmueller J (2010) Synthetic Control Methods for Comparative Case Studies: Estimating the Effect of California's Tobacco Control Program. Journal of the American Statistical Association 105(490), 493-505. https://doi.org/10.1198/jasa.2009.ap08746.

Abadie A, Diamond A and Hainmueller J (2015) Comparative Politics and the Synthetic Control Method. American Journal of Political Science 59(2), 495-510. https://doi.org/10.1111/ajps.12116.

Alconada HM (2012) ¿Por qué Tiene que Haber Límites A la Reelección? La Nación, 8 February. www. lanacion.com.ar/1438389-por-que-tiene-que-haber-limites-a-la-reeleccion.

Arana Araya I (2021) The 'Big Five' Personality Traits of Presidents and the Relaxation of Term Limits in Latin America. Democratization, published early online, August. https://doi.org/10.1080/13510347.2021. 1957838.

Athey S and Imbens GW (2017) The State of Applied Econometrics: Causality and Policy Evaluation. Journal of Economic Perspectives 31(2), 3-32. https://doi.org/10.1257/jep.31.2.3.

Atkinson AB, Hasell J, Morelli S et al. (2017) The Chartbook of Economic Inequality. Oxford: Institute for New Economic Thinking. www.chartbookofeconomicinequality.com.

Barbadillo PF (2011) Presidencias Vitalicias Para el 'Socialismo del Siglo XXI': Los Presidentes-Reyes Regresan a Iberoamérica. Cuadernos de Pensamiento Político 30, 171-187.

Baturo A (2010) The Stakes of Losing Office, Term Limits and Democracy. British Journal of Political Science 40(3), 635-662. https://doi.org/10.1017/S0007123409990056.

Baturo A (2019) Continuismo in Comparison: Avoidance, Extension, and Removal of Presidential Term Limits. In Baturo A and Elgie R (eds), The Politics of Presidential Term Limits. Oxford: Oxford University Press, pp. 75-100.

Baturo A and Elgie R (2019) Presidential Term Limits. In Baturo A and Elgie R (eds), The Politics of Presidential Term Limits. Oxford: Oxford University Press, pp. 1-16.

Bergougui B and Murshed SM (2020). New Evidence on the Oil-Democracy Nexus Utilising the Varieties of Democracy Data. Resources Policy 69, 101905. https://doi.org/10.1016/j.resourpol.2020.101905.

Bolt J and van Zanden JL (2015) IISH Data Collection, V1, GDP per Capita. https://hdl.handle.net/10622/ 8FCYOX.

Buben R and Kouba K (2020) Nicaragua in 2019: The Surprising Resilience of Authoritarianism in the Aftermath of Regime Crisis. Revista de Ciencia Política 40(2), 431-455. https://doi.org/10.4067/S0718090X2020005000114.

Burkhart RE and Lewis-Beck MS (1994) Comparative Democracy: The Economic Development Thesis. American Political Science Review 80(4), 903-910. https://doi.org/10.2307/2082715.

Carey JM (2003) The Reelection Debate in Latin America. Latin American Politics and Society 45(1), 119-133. https://doi.org/10.1111/j.1548-2456.2003.tb00234.x.

Carreras M (2012) The Rise of Outsiders in Latin America, 1980-2010: An Institutionalist Perspective. Comparative Political Studies 45(12), 1451-1482. https://doi.org/10.1177\%2F0010414012445753. 
Cassani A (2020) Autocratisation by Term Limits Manipulation in Sub-Saharan Africa. Africa Spectrum 55(3), 228-250. https://doi.org/10.1177/0002039720964218.

Cheibub JA and Medina A (2019) The Politics of Presidential Term Limits in Latin America. In Baturo A and Elgie R (eds), The Politics of Presidential Term Limits. Oxford: Oxford University Press, pp. 517-534.

Close D (2019) Presidential Term Limits in Nicaragua. In Baturo A and Elgie R (eds), The Politics of Presidential Term Limits. Oxford: Oxford University Press, pp. 159-177.

Coppedge M, Gerring J, Knutsen CH et al. (2019) V-Dem [Country-Year/Country-Date] Dataset v9. Varieties of Democracy (V-Dem) Project. www.v-dem.net/en/.

Corrales J (2009) Volatilidad Económica, Debilidad de Partidos Y el Neocaudillismo en América Latina. Journal of Democracy en Español 1, 55-76.

Corrales J and Penfold M (2014) Manipulating Term Limits in Latin America. Journal of Democracy 25(4), 157-168. https://doi.org/10.1353/jod.2014.0066.

Crespo IM and Garrido AR (2008) Elecciones y Sistemas Electorales Presidenciales en América Latina. Mexico City: Miguel Angel Porrua.

De Kadt D and Wittels SB (2019). Democratization and Economic Output in Sub-Saharan Africa. Political Science Research and Methods 7(1), 63-84. https://doi.org/10.1017/psrm.2016.15.

Del Campo E (2009) Reelección Presidencial y Rendición de Cuentas: ¿De Verdad es tan mala la Reelección? Madrid: Fundación Carolina.

Dix RH (1992) Democratization and the Institutionalization of Latin American Political Parties. Comparative Political Studies 24(4), 488-511. https://doi.org/10.1177/0010414092024004004.

Economic Commission for Latin America and the Caribbean (2019) Total Annual Gross Domestic (GDP) per Capita at Constant Prices in Dollars. https://estadisticas.cepal.org/cepalstat/tabulador/ ConsultaIntegrada .asp ?IdAplicacion $=6 \&$ idTema $=131$ \&idIndicador $=2206 \&$ idioma $=$ i .

Freedom House (2021) Freedom in the World: Country and Territory Ratings and Statuses, 1973-2021. https://freedomhouse.org/report/freedom-world.

Gaviria WT (2009) Análisis del Proceso Reeleccionista en Colombia. Reseña a Partir de Partidos Políticos: Temporalidad del Poder y Medios de Comunicación. Saber, Ciencia y Libertad 4(1), 59-76.

Ginsburg T, Melton J and Elkins Z (2011) On the Evasion of Executive Term Limits. William \& Mary Law Review 52(6), 1807-1872.

Gobillon L and Magnac T (2016) Regional Policy Evaluation: Interactive Fixed Effects and Synthetic Controls. Review of Economics and Statistics 98(3), 535-551. https://doi.org/10.1162/REST_a_00537.

Goertzel TG (1999) Fernando Henrique Cardoso: Reinventing Democracy in Brazil. Boulder, CO: Lynne Rienner.

Guliyev F (2009) End of Term Limits: Monarchical Presidencies on the Rise. Harvard International Review, 28 February. https://ssrn.com/abstract=1417532.

Heckman JJ (1976) The Common Structure of Statistical Models of Truncation, Sample Selection and Limited Dependent Variables and a Simple Estimator for Such Models. Annals of Economic and Social Measurement 5(4), 475-492.

Hellwig T and Samuels D (2008) Electoral Accountability and the Variety of Democratic Regimes. British Journal of Political Science 38(1), 65-90. https://doi.org/10.1017/S0007123408000045.

Honaker J and King G (2010) What to Do about Missing Values in Time-Series Cross-Section Data. American Journal of Political Science 54(2), 561-581. https://doi.org/10.1111/j.1540-5907.2010.00447.x.

Honaker J, King G and Blackwell M (2011) Amelia II: A Program for Missing Data. Journal of Statistical Software 45(7), 1-47. https://doi.org/10.18637/jss.v045.i07.

Houle C (2009) Inequality and Democracy: Why Inequality Harms Consolidation but Does not Affect Democratization. World Politics 61(4), 589-622. https://doi.org/10.1017/S0043887109990074.

Klesner JL (2019) The Politics of Presidential Term Limits in Mexico. In Baturo A and Elgie R (eds), The Politics of Presidential Term Limits. Oxford: Oxford University Press, pp. 141-158.

Kouba K (2016) Party Institutionalization and the Removal of Presidential Term Limits in Latin America. Revista de Ciencia Política 36(2), 433-457. https://doi.org/10.4067/S0718-090X2016000200002.

Levitsky S and Murillo MV (2020) La Tentación Militar en América Latina. Nueva Sociedad 285, 4-11.

Linz JJ (1994) Presidential or Parliamentary Democracy: Does It Make a Difference? In Linz JJ and Valenzuela A (eds), The Failure of Presidential Democracy. Baltimore, MD: Johns Hopkins University Press, pp. 3-87. 
Linz JJ (1998) Democracy's Time Constraints. International Political Science Review 19(1), 19-37. https:// doi.org/10.1177/019251298019001002.

Lührmann A, Marquardt KL and Mechkova V (2020). Constraining Governments: New Indices of Vertical, Horizontal, and Diagonal Accountability. American Political Science Review 114(3), 811-820. https://doi.org/10.1017/S0003055420000222.

Maddison A (2010) Statistics on World Population, GDP and Per Capita GDP, 1-2008 AD. www.ggdc.net/ maddison/oriindex.htm.

Mainwaring S and Shugart MS (1997) Juan Linz, Presidentialism, and Democracy: A Critical Appraisal. Comparative Politics 29(4), 449-471. https://doi.org/10.2307/422014.

Maltz G (2007) The Case for Presidential Term Limits. Journal of Democracy 18(1), 128-142. https://doi. org/10.1353/jod.2007.0010.

Manin B, Przeworski A and Stokes SC (2001) Elections and Representation. In Manin B, Przeworski A and Stokes SC (eds), Democracy, Accountability, and Representation. Cambridge: Cambridge University Press, pp. 29-48.

Marsteintredet L (2019) Presidential Term Limits in Latin America: C. 1820-1985. In Baturo A and Elgie R (eds), The Politics of Presidential Term Limits. Oxford: Oxford University Press, pp. 103-122.

McKie K (2019) Presidential Term Limit Contravention: Abolish, Extend, Fail, or Respect? Comparative Political Studies 52(10), 1-35. https://doi.org/10.1177/0010414019830737.

Negretto GL (2011) Shifting Constitutional Designs in Latin America: A Two-Level Explanation. Texas Law Review 89(7), 1777-1805.

Negretto GL (2012) Replacing and Amending Constitutions: The Logic of Constitutional Change in Latin America. Law \& Society Review 46(4), 749-779. https://doi.org/10.1111/j.1540-5893.2012.00516.x.

O’Donnell GA (1994) Delegative Democracy. Journal of Democracy 5(1), 55-69. http://doi.org/10.1353/jod. 1994.0010.

O’Donnell GA (1998). Horizontal Accountability in New Democracies. Journal of Democracy 9(3), 112126. https://doi.org/10.1353/jod.1998.0051.

Olper A, Curzi D and Swinnen J (2018) Trade Liberalization and Child Mortality: A Synthetic Control Method. World Development 110, 394-410. https://doi.org/10.1016/j.worlddev.2018.05.034.

Pemstein D, Marquardt KL, Tzelgov E et al. (2019) The V-Dem Measurement Model: Latent Variable Analysis for Cross-National and Cross-Temporal Expert-Coded Data. V-Dem Working Paper No. 21. 4th edition. University of Gothenburg: Varieties of Democracy Institute.

Raaflaub KA and Wallace RW (2007) 'People's Power' and Egalitarian Trends in Archaic Greece. In Raaflaub KA, Ober J and Wallace RW (eds), Origins of Democracy in Ancient Greece. Berkeley: University of California Press, pp. 22-48.

Ross ML (2001) Does Oil Hinder Democracy? World Politics 53, 325-361. https://doi.org/10.1353/wp.2001. 0011.

Rouquié A (2011) A la Sombra de las Dictaduras: La Democracia en América Latina. Buenos Aires: Fondo de Cultura Económica.

Sánchez IT (2013) Las Reformas a la Reelección Presidencial en América Latina. Estudios Sociológicos 30(91), 59-85.

Singh SP (2019). Compulsory Voting and Parties' Vote-Seeking Strategies. American Journal of Political Science 63 (1), 37-52. https://doi.org/10.1111/ajps.12386.

Smith PH (2005) Democracy in Latin America. Oxford: Oxford University Press.

Solt F (2019) The Standardized World Income Inequality Database. SWIID Version 8.2. https://doi.org/10. 7910/DVN/LM4OWF.

Stefanoni P (2020) Las Lecciones que nos Deja Bolivia. Nueva Sociedad, March. www.nuso.org/articulo/ Bolivia-Evo-Morales-elecciones/.

Toomet $\mathbf{O}$ and Henningsen A (2008) Sample Selection Models in R: Package SampleSelection. Journal of Statistical Software 27(7). http://dx.doi.org/10.18637/jss.v027.i07.

United Nations Development Programme, Human Development Reports (2019) Human Development Index (HDI). http://hdr.undp.org/en/content/human-development-index-hdi.

Wolff J (2020) The Turbulent End of an Era in Bolivia: Contested Elections, the Ouster of Evo Morales, and the Beginning of a Transition towards an Uncertain Future. Revista de Ciencia Politica 40(2), 163-186. https://doi.org/10.4067/S0718-090X2020005000105. 
World Bank (2019a) GDP per Capita (constant 2010 US\$). https://data.worldbank.org/indicator/NY.GDP. PCAP.KD.

World Bank (2019b) GINI Index (World Bank estimate). https://data.worldbank.org/indicator/SI.POV. GINI.

World Bank (2019c) Total Natural Resources Rents (\% of GDP). https://data.worldbank.org/indicator/NY. GDP.TOTL.RT.ZS.

World Economic Forum (2018) Inclusive Development Index. www.weforum.org/reports/the-inclusivedevelopment-index-2018.

Xu Y (2017) Generalized Synthetic Control Method: Causal Inference with Interactive Fixed Effects Models. Political Analysis 25(1), 57-76. https://doi.org/10.1017/pan.2016.2.

Zovatto D (2005) Costa Rica. In Nohlen D (ed.), Elections in the Americas: A Data Handbook. Vol I North America, Central America, and the Caribbean. Oxford: Oxford University Press, pp. 147-194.

Zovatto D (2014) Latin America: Re-Election and Democracy. Open Democracy, 4 March. www.opendemocracy.net/en/latin-america-re-election-and-democracy/.

Cite this article: Kouba K, Pumr J (2023). The Democratic Cost of Consecutive Re-election and Presidential Term-Limit Evasion in Latin America. Government and Opposition: An International Journal of Comparative Politics 58, 360-390. https://doi.org/10.1017/gov.2021.51 